\title{
Helping Individuals vs. Fixing the System: Distinguishing Facets of Adolescent Civic Reasoning
}

Lauren M. Alvis

Follow this and additional works at: https://researchrepository.wvu.edu/etd

\section{Recommended Citation}

Alvis, Lauren M., "Helping Individuals vs. Fixing the System: Distinguishing Facets of Adolescent Civic Reasoning" (2017). Graduate Theses, Dissertations, and Problem Reports. 5091.

https://researchrepository.wvu.edu/etd/5091

This Thesis is protected by copyright and/or related rights. It has been brought to you by the The Research Repository @ WVU with permission from the rights-holder(s). You are free to use this Thesis in any way that is permitted by the copyright and related rights legislation that applies to your use. For other uses you must obtain permission from the rights-holder(s) directly, unless additional rights are indicated by a Creative Commons license in the record and/ or on the work itself. This Thesis has been accepted for inclusion in WVU Graduate Theses, Dissertations, and Problem Reports collection by an authorized administrator of The Research Repository @ WVU. For more information, please contact researchrepository@mail.wvu.edu. 
Helping individuals vs. fixing the system: Distinguishing facets of adolescent civic reasoning

Lauren M. Alvis, B.A.

Thesis submitted to the Eberly College of Arts and Sciences

at West Virginia University in partial fulfillment of the requirements

for the degree of

Master of Science

in

Life-Span Developmental Psychology

Aaron Metzger, Ph.D., Chair

Amy Gentzler, Ph.D.

Natalie Shook, Ph.D.

Department of Psychology

Morgantown, West Virginia

2016

Keywords: civic engagement, moral reasoning, political participation, citizenship, civic development

Copyright 2016 Lauren M. Alvis 


\begin{abstract}
Helping individuals vs. fixing the system: Distinguishing facets of adolescent civic reasoning

\section{Lauren M. Alvis}

The current study examined associations among adolescents' civic behaviors, sociomoral judgments, and welfare- and justice-oriented reasoning. Participants included 721 adolescents $\left(M_{\text {age }}=15.87, S D=1.28\right.$; $90 \%$ Caucasian; $55.6 \%$ female $)$ living in a University city in a MidAtlantic state. Participants completed survey questionnaires that assessed sociomoral judgments for and involvement in civic behaviors, as well as a free-response questionnaire that assessed justifications for various forms of civic engagement. Welfare-oriented reasoning was defined as justifications that reflected a sense of obligation to address the welfare of individuals in need, whereas justice-oriented reasoning was reflected in adolescents' use of structural justifications, which describe the potential for a behavior to implement systemic or macro-level change. Results indicated that justice-oriented reasoning, but not welfare-oriented reasoning, was associated positively with adolescent civic involvement. Additionally, justice-oriented reasoning was particularly integral to adolescent social movement behavior in that youth who viewed social movement as highly obligatory, important, and worthy of respect and used structural justifications were engaged in higher levels of social movement behavior than youth who viewed social movement as important for other reasons. The current findings provide nuanced insights into adolescents' developing understanding of civic behaviors and highlight the importance of investigating justice-oriented reasoning as a vital component of civic development.
\end{abstract}




\section{ACKNOWLEDGEMENTS}

I would like to thank Dr. Aaron Metzger, my academic advisor and thesis chair for his guidance and support throughout this project. I would also like to thank Dr. Amy Gentzler and Dr. Natalie Shook for the time and helpful feedback they have provided. Lastly, my family members and friends have been an incredible source of support throughout this process. I would also like to thank my fellow lab members, Katelyn Romm and Rebecca Olson for their continued support. 


\section{TABLE OF CONTENTS}

TITLE i

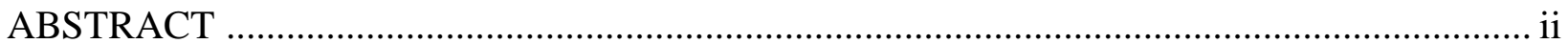

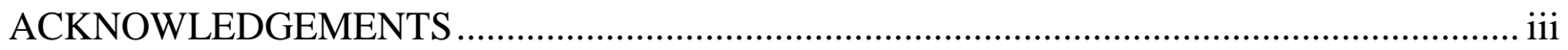

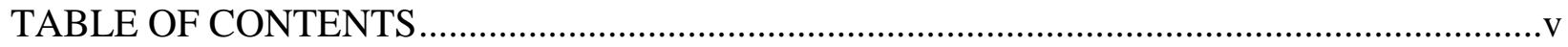

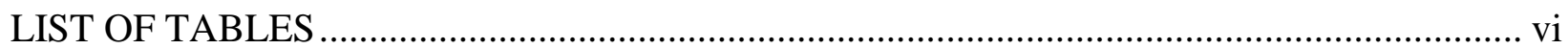

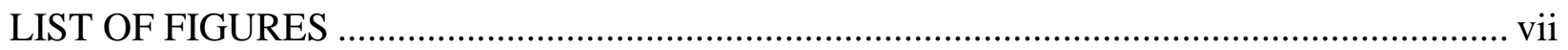

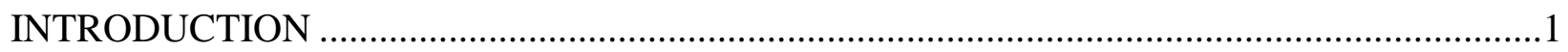

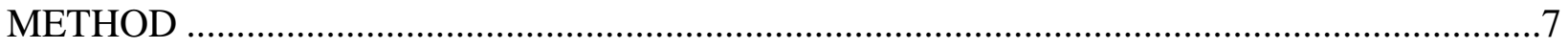

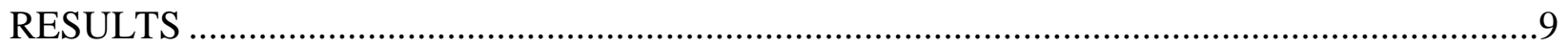

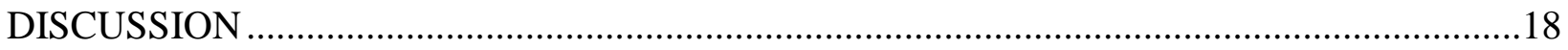

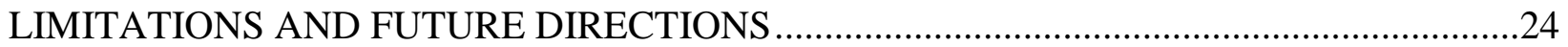

CONCLUSION

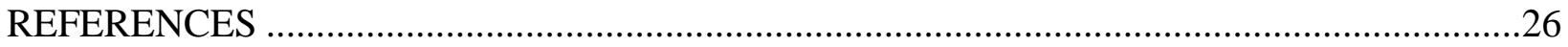

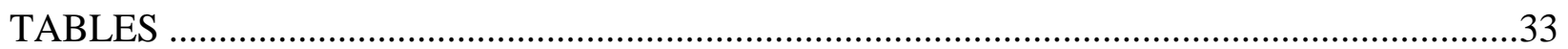

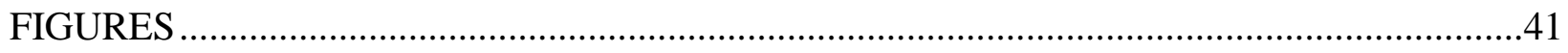

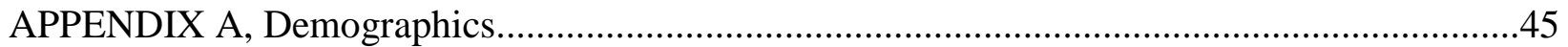

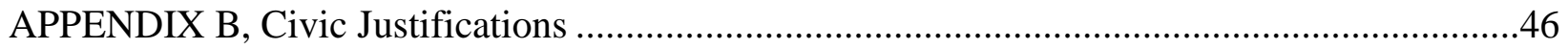

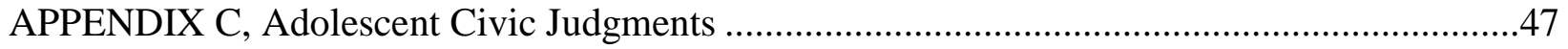

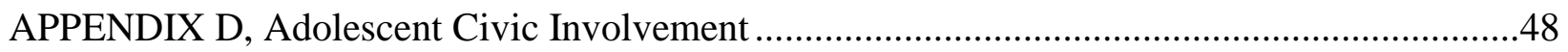

APPENDIX E, Summary of Measures for Constructs .............................................................49 
APPENDIX F, Trimmed Table of Civic Justifications .............................................................50

APPENDIX G, Extended Literature Review and Methods .............................................................53

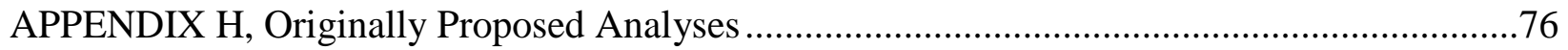

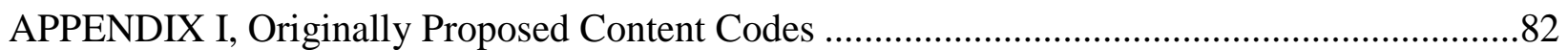




\section{LIST OF TABLES}

Table 1

Definitions, Kappa Coefficients, and Frequencies for Coded Content Categories

Table 2

Descriptive Statistics and Correlations for Civic Judgments and Civic Behaviors

Table 3

Correlations for Social Movement Judgments, Justifications, and Demographics

Table 4

Correlations for Community Service Judgments, Justifications, and Demographics

Table 5

Correlations for Standard Political Judgments, Justifications, and Demographics 


\section{LIST OF FIGURES}

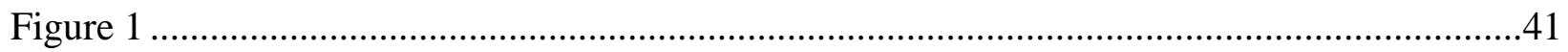

Measurement model for civic judgments

Figure 2

Civic justifications for social movement predicting social movement behavior

Figure 3

Civic justifications for community service predicting community service behavior

Figure 4

Civic justifications for standard political predicting standard political behavior 
Helping individuals vs. fixing the system: Distinguishing facets of adolescent civic reasoning A democracy’s success depends heavily on engaged citizens (Tocqueville, 1966; Snell, 2010). In the interest of enhancing civic engagement, researchers have argued that it is imperative to uncover the developmental processes that underlie active citizenship (Flanagan, \& Faison, 2002). Recently, developmental scientists have begun to investigate youth's conceptualizations of civic responsibility as a potential social-cognitive mechanism that undergirds and predicts later civic behavior (Metzger \& Ferris, 2013; Metzger, Oosterhoff, Palmer, \& Ferris, 2014; Metzger \& Smetana, 2009; Westheimer \& Kahne, 2004). Research indicates that youth have distinct civic orientations regarding the importance of civic responsibility, as some involved youth stress the importance of contributing to the welfare of others, while others emphasize the need to implement macro-level change to address social injustice (Westheimer \& Kahne, 2004; Yates \& Youniss, 1996a). For example, when confronted by a homeless person, some individuals may focus on this particular individual's needs and directly offer assistance (welfare-oriented citizens) whereas other individuals may look beyond this individual's needs and instead examine the contextual factors that contribute to homelessness and consider a course of action that can address the political, economic, or social structures that underlie these problems (justice-oriented citizens; Westheimer \& Kahn, 2004; Wainryb, 1991). It has been theorized that these distinct orientations (e.g., welfare- vs. justicefocused civic beliefs) are each associated with specific forms of civic action (Westheimer \& Kahne, 2004). However, there has been little empirical investigation into the presence of different civic orientations as it relates to youth's judgments of and engagement in specific types of civic activities. 
Grounded in social domain theory (Smetana, 2006), other lines of research have explored adolescents' sociomoral reasoning about different types of civic activity including judgments concerning the importance, obligatory nature, and moral worthiness of civic engagement, and these civic judgments have been associated in domain-specific ways with youth's civic behavior (Metzger \& Smetana, 2009). However, this research has not considered how sociomoral judgments intersect with a welfare- vs. justice-oriented understanding of civic engagement. Variation among adolescent civic beliefs may reveal distinct conceptualizations of civic responsibility that point to developmental origins of different forms of active citizenship.

Civic engagement is a multifaceted construct that encompasses a wide range of civic, community, and political behaviors (Galston, 2007; Metzger \& Smetana, 2010). Traditionally, political scientists used the term civic engagement to refer strictly to standard political involvement (e.g., voting in a political election; Walker, 2000). Developmental psychologists have broadened the definition of civic engagement to include voluntary activities intended to serve others or the community (community service) and "social-cause" political activities (social movement; Torney-Purta, Lehmann, Oswald, \& Schulz, 2001). Although all forms of civic action involve prosocial behaviors aimed at helping others, bettering one's community, or benefiting greater societal institutions, prior research shows that adolescents view social movement, community service, and standard political activities as conceptually and behaviorally distinct forms of civic involvement (Metzger \& Smetana, 2009). Engagement in these different civic behaviors may be associated with unique conceptualizations of civic responsibility. Understanding adolescents' beliefs about civic responsibility - and how these beliefs are grounded in their moral values - may provide insight into the developmental antecedents of civic 
engagement. Moral and civic developmental theory and research has long recognized justice and care or concern for others' welfare, as distinct moral principles that are important for understanding social development (Killen \& Malti, 2015; Gilligan, 1982; Wray-Lake \& Syvertsen, 2011). However, relatively less research has considered whether conceptualizations of justice and welfare have different implications for civic development. For instance, scholars posit that some citizens are oriented toward compassion for individuals in need (i.e., welfare-oriented citizens) and are likely to participate in civic behaviors that involve directly addressing the needs of others such as community service. In contrast, other citizens who emphasize justice at the societal or institutional level (i.e., justice-oriented citizens) are likely to engage in collective forms of political action aimed at macro-level change such as social movement activities like political protest (Westheimer \& Kahne, 2004). Justice-oriented citizens are theorized to employ a critical or structural analysis of social issues and focus on how they can improve society or a community by making systemic level changes. Thus, a core facet of a justice-oriented understanding of civic responsibility is a structural perspective (i.e., focus on root causes of social injustice and importance of implementing macro-level change). However, few studies have empirically investigated whether and how youth employ a structural perspective when reasoning about civic responsibility and different forms of civic behavior.

Although empirical examination of this process is lacking, previous qualitative research suggests that civically engaged youth may differentially emphasize welfare and justice when reasoning about civic responsibility. Interviews with youth involved in different service-learning programs revealed that students who participated in social movement behaviors aimed at social justice emphasized root societal and institutional causes when reasoning about social problems 
(e.g., poverty is caused by a shortage of jobs that pay high enough wages to support one's self) and the importance of systemic level change (i.e., justice-orientation; Westheimer \& Kahne, 2004). Other studies utilizing semi-structured interviews, in contrast, have found that individuals involved in community service tend to focus on compassion and a concern for other individuals (i.e., welfare-orientation; Yates \& Youniss, 1996a). Extending this qualitative research by empirically investigating how welfare- vs. justice-oriented civic beliefs map onto adolescents' evaluations of and engagement in different civic activities is vital to advancing research on civic and moral development.

Although little research has quantified youths' welfare- and justice-oriented reasoning about specific civic behaviors, research from a social domain perspective has investigated adolescents' sociomoral judgments about civic engagement, which are an important facet of adolescents' budding civic beliefs. Informed by moral philosophy and social domain research, several studies have assessed adolescents' judgments about whether individuals should engage in civic activities, whether it is wrong not to participate (assessing moral obligation; Kohlberg, 1997), and whether civic involvement is "worthy of social praise" (Metzger \& Smetana, 2009; Metzger \& Ferris, 2013). Research has demonstrated that adolescents' judgments about civic behaviors are associated positively with their engagement in parallel behaviors. For instance, views of community service involvement as highly obligatory, important, and morally worthy were associated with higher levels of community service involvement among adolescents (Metzger \& Smetana, 2009).

Justifications for civic involvement are another integral facet of adolescents' civic beliefs, allowing researchers to evaluate not just whether individuals think civic involvement is 
important (sociomoral judgments), but why they think various civic behaviors are important (civic justifications). According to social domain theory, individuals interpret their social worlds from different domains of social knowledge and draw on these domains when reasoning about different types of social behaviors and events (Smetana, 2006). Adolescents systematically apply domain-specific justifications and judgments to different civic behaviors (Metzger \& Ferris, 2014; Metzger \& Smetana, 2009). For instance, adolescents viewed community service involvement as moral in that they rated it as highly obligatory and worthy of social praise for moral reasons (i.e., justifications that reflect concern for welfare, fairness, or rights; Metzger \& Smetana, 2009). Given the overt prosocial nature of community service, adolescents may attribute the importance of community service to the direct effect it can have on individuals' welfare. Thus, justifications that specifically reflect welfare concern may be particularly important for adolescents' judgments about community service activities.

Although previous social domain research captured justifications that may reflect a welfare-orientation (moral justifications), this research has not considered civic justifications that reflect a justice-orientation. When reasoning about why civic engagement is important, some youth may employ a structural perspective and focus on macro-level change and systemic causes of social issues. For example, when reasoning about why people should take part in political protest, some adolescents may focus on the ways in which protest can lead to important changes in political policy. This structural perspective may intersect with adolescents' sociomoral judgments for specific civic behaviors. Adolescents who apply structural justifications may be especially inclined to view behaviors that address systemic level change, such as social movement, as obligatory, important, and worthy of respect. 
The current research further extends existing work on moral development by examining the interactive effects of civic judgments and civic justifications. Moral development researchers have traditionally treated judgments and justifications as distinct and additive components of social and moral reasoning (Turiel, 2002). Less empirical work has considered ways in which these dimensions may operate interactively in predicting behavior. Adolescents' civic judgments (obligation and social praise) are associated positively with engagement in similar types of activities (Metzger \& Smetana, 2009). However, there may be individual differences in this association based on adolescents' reasons for why these different activities are important (justifications). That is, qualitatively distinct civic justifications may interact and intersect with adolescents' sociomoral reasoning about civic behaviors, and the association between civic judgments and behaviors may be amplified in the presence of different civic justifications. For instance, a structural perspective may interact with sociomoral judgments to predict specific forms of civic engagement, particularly social movement behaviors. Positive associations between social movement judgments and social movement involvement may be stronger for youth who view social movement as important for structural reasons. That is, adolescents who view social movement as highly obligatory, important, and worthy of respect and consider the potential for social movement activities to create systemic change will be more involved compared to adolescents who prioritize social movement involvement for other reasons. Similarly, adolescents who prioritize community service involvement in their sociomoral judgments are more involved in community service activities (Metzger \& Smetana, 2009). However, associations between community service judgments and behavior may be stronger for adolescents who view community service as important for welfare-oriented reasons. Thus, 
distinct patterns may emerge across adolescents' civic beliefs and behaviors that reflect developmental origins of different types of citizens (justice-oriented and welfare-oriented citizens).

The current study examined the extent to which distinct conceptualizations of civic engagement (justice- vs. welfare-oriented) map onto adolescents' prioritization of and engagement in different forms of civic activities. First, we investigated how adolescents reason about different forms of civic engagement by assessing their civic justifications and sociomoral judgments for social movement, community service, and standard political involvement. To add to previous literature on adolescent civic reasoning, a free-response methodology was used to assess a broader range of youth justifications for civic involvement. Further, associations among adolescent civic behaviors, civic justifications, and sociomoral judgments were examined. The current study will also build on previous research by exploring the interactive effects of civic judgments and justifications. We sought to identify how associations between civic involvement and civic judgments vary as a function of civic justifications. Overall, the primary aim of the present study was to improve our understanding of how adolescents develop into different types of active citizens.

\section{Method}

\section{Participants}

Participants were 743 adolescents $\left(M_{\mathrm{age}}=15.87, S D=1.28\right.$, range $=13-20$ years, $55.6 \%$ female) from a small rural town $(n=376)$ and a mid-sized University city $(n=367)$ in the Appalachian region of the United States. Adolescents were primarily Caucasian/White (90\%), 5\% reported African American/Black, 2\% reported Asian American/Pacific Islander, 2\% 
Hispanic/Latino, and 1\% reported Native American. Adolescents' reports of their parents' education indicated that $53 \%$ of mothers and $48 \%$ of fathers completed college or a graduate degree. Twenty-eight percent of adolescents reported they received Mostly A's and 39\% reported a mixture of A's and B's on their school grades.

\section{Procedure}

All students at the high schools were offered the opportunity for participation.

Recruitment and survey administration for ninth- through twelfth-grade students took place in social studies classrooms. Only students who assented and obtained parental consent were administered a survey. The surveys were administered by research team members who remained present to answer questions about the survey and to provide instructions. Participants who completed the survey were eligible to win a randomly drawn cash prize ranging from $\$ 25$ to $\$ 100$.

\section{Civic Coding}

Participants were asked three free response questions that assessed adolescents’ justifications for why people should take part in specific forms of civic action. They were instructed to provide reasons that they think best explains why people should or should not participate in a political protest or rally (social movement), volunteer to feed the homeless (community service), and vote in political elections (standard political). Participants were instructed to write down the 1-2 most important reasons for participating in the civic activity. 
Coding Process. The content of adolescents' justifications for why people should take part in three civic behaviors was coded for themes related to domains of social reasoning and other sociomoral concepts. Two coders, the author and a reliability coder, analyzed participants' civic justifications. A training manual was created in conjunction with training meetings to help establish reliability between the two coders. Training consisted of two coders separately coding one set of 25 cases per week and then meeting to exchange notes which were used to update the coding manual. Interrater reliability was considered adequate when kappa coefficients on jointly coded cases reached .60 (Cohen, 1960; Lance, 2006). After acceptable reliability was established, the author independently coded all of the cases and the reliability coder coded $25 \%$ of the cases.

Content Coding. The coding system was designed to assess the substance of participants' written statements within a free-response question task and assign specific codes based on the types of information reported in those statements. A central assumption in this approach is that participants' written statements reflect individuals' beliefs about why individuals should be engaged in three different civic behaviors (protesting, volunteering, and voting). The current coding scheme was developed based on a subset of responses, theory, previous research (Helwig, 1998; Helwig et al., 2003), and discussions with experts in the field. After reading each answer comprised of multiple statements, coders assessed whether the statements contained any material relevant to the codes. A single codable statement began when a new idea was introduced and ended when the idea was concluded or when punctuation indicated the end of a sentence. Each statement within an individual's response received only one code. However, participants could respond with multiple statements for each question, thus 
individuals could receive multiple codes. Participants received score of either 0 (absent) or 1 (present) for each coding category. A total of 29 content codes were created, however, categories that had low frequencies (less than 10\%) and were not conceptually similar were excluded from analyses (see Table 1 for code descriptions, kappa coefficients, and frequencies). Thus, a total of 17 codes were considered in the current study.

A total of four content codes were used to assess adolescents' responses to why people should or should not take part in political protest or rally (Table 1a). Four content codes were used to assess youths' reasoning for why people should or should vote in political elections (Table 1c). For responses for both protest and voting behaviors, a structural justification was defined as reasons that describe macro-level change and fixing problems at systemic level (e.g., change policy, influence future of the government; $\kappa=.62-.72$ ). A total of seven content codes were used to assess adolescents' responses to why people should or should not volunteer to feed the homeless (Table 1b). Two codes that were conceptually similar were collapsed to represent structural justifications for volunteering: root causes and community change. Root causes was defined as reasons for helping based on beliefs that homelessness is a result of societal inequalities or other external forces, rather than individuals' disposition (i.e., it is not their fault; $\kappa=.70$ ). These statements described the causes of homelessness (e.g., we should help because it is not their fault they are homeless, the economy is so bad that people cannot get a job or afford rent). Statements that described macro- or community-level changes, as opposed to protecting an individual's welfare, were coded as community change (e.g., we should volunteer to feed the homeless because it will strengthen the community and make it a better place for everyone; $\kappa=$ .69). A welfare-oriented moral justification (labelled as welfare in results) was defined as a 
concern for the welfare of others and an obligation to help individuals in need (e.g., we should help feed the homeless because it's wrong to let humans starve, $\kappa=.62$ ).

\section{Quantitative In-Survey Measures}

In addition to the qualitative justifications described above, the questionnaire included multiple quantitative measures assessing adolescents' civic prioritization judgments and involvement in community service, social movement, and standard political activity.

Civic activity categories. Consistent with previous research (Metzger \& Smetana, 2009; Metzger \& Ferris, 2013), adolescents' civic judgments were assessed using 13 items from an established measure of civic engagement. Four items assessed social movement involvement (i.e., write to a newspaper, magazine, blog, or website about a social or political issue, take part in a political protest or rally, work to change a law that they disagree with, distribute a petition for a cause). Five items assessed community service involvement (i.e. volunteer for a fundraiser aiding victims of a natural disaster, volunteer to help disabled students at your school, volunteer to help the people in your community, volunteer to help feed the homeless people). Five items assessed standard political involvement (i.e. keep up with current events and politics, join a political party, work on a political campaign, vote in a political election, know who their elected representatives and leaders are).

Should judgments. Participants rated whether individuals "should" take part in each of the 13 civic involvement items. Responses were measured with a 5-point Likert scale ranging from 1 (doesn't matter) to 5 (definitely should). Higher ratings indicate stronger feelings that people should be engaged in each civic activity. 
Obligation judgments (wrong). Participants reported how "wrong" it is not to take part in in the 13 civic involvement items. Responses were measured with a 5-point Likert scale ranging from 1 (not at all wrong) to 5 (very wrong). Higher scores indicate stronger feelings of obligation for each civic activity.

Respect judgments. Participants reported the praiseworthiness of 13 civic activities by rating how much they would respect someone who takes part in 13 civic involvement items. Responses were measured with a 5-point Likert scale ranging from 1 (none at all) to 5 (a lot). Consistent with previous research, higher ratings indicated stronger beliefs that involvement in the civic activity is worthy of social praise (respect), which moral philosophers have argued is an important attribute for distinguishing prosocial moral behavior from other forms of prosocial activity (Metzger \& Smetana, 2009).

Civic Involvement. Adolescent civic behaviors were measured using 8 items from a 25 item questionnaire assessing general civic involvement. These items measured involvement in volunteering ( 3 items), social movement ( 2 items), and standard political activity (3 items). Items assessed current involvement over the past 30 days. Responses were given on a 5-point Likert scale ranging from 1 (never) to 5 (very often).

\section{Planned Analyses}

Data were analyzed using structural equation (SEM) modeling with maximum likelihood estimation in SPSS AMOS 24. If a proposed model yielded poor fit to the data, non-significant parameters and variables were removed from the model and a chi-square difference test was conducted to ensure the trimmed model provided a significantly improved model fit. Variables with significant bivariate correlations were allowed to covary. Significant parameters $(p<.05)$ 
were interpreted upon achieving adequate model fit $\left(\chi^{2} / \mathrm{df}<3.00, \mathrm{CFI}>.90, \mathrm{RMSEA}<.08\right)$. Justifications were analyzed using dummy codes that represented the presence (1) vs. absence (0) of each justification.

Behavior-specific correlations among justifications and judgments were assessed in SEM (e.g., associations between volunteering justifications and community service judgments). To test how adolescents' civic beliefs (judgments and justifications) were associated with their engagement in civic activities, a series of structural equation models were conducted. Separate structural models were performed for each civic behavior category with justifications and firstorder latent variables representing civic judgments identified as exogenous variables predicting latent variables representing civic behaviors, while controlling for adolescent gender, age, and parental education. To assess whether associations between civic judgments and behaviors varied as a function of adolescents' justifications, multi-group analyses were performed. To test for moderation by justifications, the fit of an unconstrained model that freely estimated structural pathways for youth who used a justification and youth who did not (e.g., youth with structural justification present vs. youth with a structural justification absent) was compared to the fit of a model that constrained structural pathways to be equal across the two groups. When the unconstrained model provided a significantly better model fit, critical ratios were examined to determine whether the specific pathway of interest significantly differed as a function of adolescents' civic justifications.

\section{Results}

\section{Preliminary Analyses}


Due to low frequency of some of the content codes, categories that were conceptually similar were collapsed. Specifically, root causes and community change codes for volunteering were collapsed into one category that represented structural justifications for volunteering. Additionally, perceived reciprocity and inequality were collapsed into one category that represented fairness justifications for volunteering. Other codes with low frequencies $(<10 \%)$ and low inter-rater consistency (kappa $<.60)$ were exclude from analyses.

Scale level mean imputation was utilized for missing values on self-report measures for each of the civic judgment subscales. Twenty-two participants did not complete the freeresponse portion of the questionnaire. These participants did not significantly differ in terms of age, parental education, academic grades, gender, or civic scales. All analyses were conducted utilizing the full sample (with 22 participants receiving a score of 0 for each justification) and using the reduced sample (22 participants removed). Model fit indices and parameters were identical for both samples. The reported results are based on the reduced sample $(n=721)$. Means, standard deviations, and correlations among adolescent civic judgments and behaviors within and across each behavior category are reported in Table 2.

\section{Adolescents' beliefs (judgments and justifications) about civic involvement}

Consistent with previous studies (Metzger \& Smetana, 2009; Metzger et al., 2010), latent variables for social movement judgments, community service judgments, and standard political judgments were created that used the should, wrong, and respect scales as indicators. First, a measurement model was examined using confirmatory factor analysis (CFA) to determine whether the proposed latent variables provided a good fit to the data matrix. The latent variables as well as the error terms for similar subscales across latent variables (e.g., error terms for the 
should indicators) were allowed to covary to improve model fit. The resulting measurement model provided a good fit to the data, $\chi^{2} / \mathrm{df}=1.80, \mathrm{CFI}=0.99, \mathrm{RMSEA}=0.03$ (see Figure 1 ).

Next, associations among justifications and judgments within each behavior category were tested using structural equation modeling (SEM). Correlations between civic justifications and civic judgments were generally small to moderate in magnitude $(r \mathrm{~s}=.01-.25, p \mathrm{~s}=.001$ .25; see Tables 3-5). For adolescent social movement beliefs, all protest justifications were significantly associated with social movement judgments (Table 3). Specifically, structural, voice beliefs, and duty justifications were significantly associated positively with adolescent social movement judgments, $r \mathrm{~s}=.01-.16, p \mathrm{~s}<.05$ whereas personal justifications were associated negatively, $r=-.08, p<.001$. For community service beliefs, volunteering justifications that reflected welfare, fairness, structural perspective, and description were each significantly associated positively with adolescent judgments about community service involvement, $r \mathrm{~s}=.08-.23, \mathrm{ps}<.05$ (Table 4). Justifications that reflected good boy/girl were not significantly associated with community service judgments. For standard political beliefs, with the exception of candidate specific justifications, all voting justifications were significantly associated with standard political judgments, $\mathrm{rs}=.13-.25$, $\mathrm{ps}<.01$ (Table 5).

\section{Civic justifications predicting adolescent civic involvement}

To examine the associations between justifications and behavior, structural equation models were performed with justifications identified as exogenous variables predicting firstorder latent variables representing civic involvement, while controlling for adolescent gender, age, and parental education. The resulting models for social movement, community service, and standard political involvement yielded good model fit, $\chi^{2} / \mathrm{df}=1.48-2.02, \mathrm{CFI}=0.94-0.99$, 
RMSEA $=0.03-0.04$ (see Figures 2-4). Results from the separate models for each behavior are reported next.

Social movement. The initial model in which 5 justifications for social movement (i.e., structural, voice beliefs, personal, duty, shouldn't) predicted adolescent social movement involvement provided poor model fit. A series of modifications were made in which nonsignificant pathways were trimmed which significantly improved model fit, $\Delta \chi^{2}=69.74, d f=19$, $p<.001$ (see Figure 2). The results indicated that only structural and personal justifications for protesting were significantly associated with adolescent social movement behavior. Youth who reasoned about protest from a structural perspective were more involved in social movement activities compared to youth who did not use structural justifications $(\beta=.12, p=.011)$. In contrast, youth who utilized personal justifications were less involved in social movement activities compared to youth did not use personal justifications $(\beta=-.10, p=.034)$.

Community Service. A structural equation model was performed with five justifications for why people should volunteer (i.e., structural, welfare, fairness, good boy/girl, and description) predicting adolescent community service involvement (see Figure 3). The results indicated that of the justifications for volunteering, only justifications that reflected a structural perspective significantly predicted adolescent community service involvement. Youth who reasoned about volunteering to feed the homeless in terms of the structural implications were more involved in community service compared to youth who did not use structural justifications for volunteering $(\beta=.10, p=.01)$.

Standard Political. A structural equation model was performed with four justifications for why people should vote in political elections (i.e., structural, voice beliefs, can't complain, 
candidate specific) predicting adolescent standard political involvement yielded poor model fit. A series of modifications were made in which non-significant pathways were trimmed which significantly improved model fit, $\Delta \chi^{2}=64.18, d f=17, p<.001$ (see Figure 4). The results indicated that structural, can't complain, and voice beliefs, but not candidate specific, were significantly associated with standard political involvement. Associations for structural $(\beta=.18$, $p<.01)$, can't complain $(\beta=.14, p<.01)$, and voice beliefs $(\beta=.14, p<.01)$ were positive.

\section{Civic Behaviors and Civic Judgments: Civic Justifications as a moderator}

To examine the associations between civic judgments and civic behavior, structural equation models were performed with latent variables representing civic judgments predicting latent variables representing civic involvement, while controlling for adolescent gender, age, and parental education. The resulting models for social movement, community service, and standard political involvement yielded good fit, $\chi^{2} / \mathrm{df}=1.96-3.38, \mathrm{CFI}=0.93-0.95, \mathrm{RMSEA}=0.04-$ 0.06. Multi-group analyses were performed to test whether associations between civic judgments and civic involvement varied as a function of civic justifications.

Social Movement: Structural justifications. A structural equation model with social movement judgments predicting social movement involvement was performed. Consistent with prior research (Metzger \& Smetana, 2009), social movement judgments were associated positively with engagement in these activities such that youth who viewed social movement involvement as highly important, obligatory, and worthy of respect were also more engaged in social movement activities $(\beta=.57, p<.001)$. It was hypothesized that this association would be stronger for youth who viewed social movement as important for structural reasons. Multi-group analyses indicated that the fit of the model that freely estimated pathways for the two groups 
provided a good fit to the data $\left(\chi^{2} / \mathrm{df}=1.96, \mathrm{CFI}=.95, \mathrm{RMSEA}=.04\right)$ and a significantly better fit to the data than a model that constrained pathways for youth who used a structural justification and youth who did not use a structural justification, $\Delta \chi^{2}(1)=5.05, p=.025$. Posthoc examination of critical ratios indicated that the positive association between social movement judgments and behavior was significantly stronger for youth who used structural justifications for why people should protest $(\beta=.66, p<.001$, C.R. $=2.35)$ compared to youth who did not use structural justifications $(\beta=.55, p<.001)$.

Community Service: Welfare justifications. A structural equation model with social movement judgments predicting social movement involvement was performed. Consistent with prior research (Metzger \& Smetana, 2009), adolescents' judgments for community service were associated positively with their engagement in these behaviors such that youth who viewed community service involvement as highly important, obligatory, and worthy of respect were also more engaged in social movement activities $(\beta=.52, p<.001)$. It was hypothesized that this positive association would be stronger for youth who viewed community service as important for welfare-oriented moral reasons compared to youth who did not use welfare-oriented justifications. Multi-group results suggested that the fit of the unconstrained model compared to the fit of the constrained model did not significantly differ $\left(\Delta \chi^{2}(3)=2.69, p=.442\right)$. That is, the use of welfare-oriented justifications for volunteering did not significantly moderate the association between adolescents' community service judgments and community service involvement. 


\section{Discussion}

The present study provides nuanced insights into adolescents' developing civic beliefs and behaviors by merging qualitative research on youths' understanding of civic responsibility (Westheimer \& Kahne, 2004b) with recent literature on adolescents' sociomoral reasoning about specific civic behaviors (e.g., Metzger \& Smetana, 2009). In the current study, we coded adolescents' free-responses to assess civic justifications, and captured a wide range of civic conceptualizations, including reasoning that reflected justice- and welfare-orientations. We then examined how these divergent ways of understanding civic engagement interacted with sociomoral judgments to predict civic involvement. Our findings highlight the importance of examining adolescents' structural justifications for civic behavior as both an example of justiceoriented reasoning and as a vital component of adolescent civic engagement. The current study indicates that structural reasoning may be especially integral to understanding adolescents' involvement in social movement activities.

Scholars theorize that there are different types of citizens who have distinct conceptualizations of civic responsibility (Westheimer \& Kahne, 2004a, 2004b). Based on this research, it was hypothesized that, when reasoning about why people should take part in civic activities, some adolescents would express a justice-orientation (i.e., focus on macro-level change) whereas other adolescents' reasoning would reflect a welfare-orientation (i.e., focus on individuals' welfare). In the current study, adolescents' justice-orientation was assessed by adolescents' use of structural justifications which is an important facet of justice-oriented civic beliefs. Adolescents' structural justifications for civic engagement provide insights into youth's informational assumptions about political, economic, and social structures and their beliefs 
concerning the efficacy of a behavior to implement systemic change. Informational assumptions are descriptive beliefs that represent individuals' factual understanding of their social environment and previous research demonstrates that informational assumptions are associated with individuals' moral judgments (Wainryb, 1991). The current findings indicate that adolescents' factual beliefs about social-political systems and civic behaviors are linked to adolescents' sociomoral evaluation of and engagement in civic action.

According to Westheimer \& Kahne (2004b), justice-oriented citizens are characterized by their structural perspective on civic responsibility. A structural perspective includes beliefs that social issues need to be addressed by critically analyzing the structure of the system that perpetuates injustice. Such individuals focus their civic action on behaviors that have the goal of implementing macro-level change. Our findings support the notion that a structural perspective plays a critical role in understanding youth social movement behaviors. Consistent with hypotheses, adolescents who reported a justice-oriented understanding of social movement, as indicated by structural justifications (e.g., people should take part in protest because it can influence the government and change a law), viewed social movement involvement as more obligatory, important, and worthy of respect. Adolescents who gave structural justifications for social movement activities were also more engaged in these behaviors compared to adolescents who did not give structural justifications. In addition, results indicated the association between social movement judgments and behaviors varied as a function of structural justifications. Adolescents who viewed social movement involvement as highly obligatory, important, and worthy of respect and considered the ways these behaviors can lead to systemic change were engaged in higher levels of social movement behavior than adolescents who viewed social 
movement involvement as highly important, but did not give structural justifications. These individual differences in adolescent civic engagement may reflect the developmental origins of a justice-oriented form of active citizenship. Further, the interaction between structural justifications and sociomoral judgments points to the importance of examining not just whether individuals think civic action is important, but why they think it is important, as adolescents' justifications provided additional insight into their understanding of social movement as it related to their engagement in these activities. Justifications and judgments are distinct and interactive facets of adolescents' civic reasoning.

Although adolescents who rated social movement involvement as highly important were generally more involved in social movement activities, qualitative differences in youths' justifications for social movement involvement (i.e., reasons why it is important) affected the degree to which their sociomoral judgments were associated with their social movement behavior. One possibility is that involvement in social movement activities influence youths' understanding of the importance, obligatory nature, and social praise-worthiness of social movement, and for some youth, their involvement may also lead to a qualitative shift in their understanding of why the behavior is important. Engaging in behaviors aimed at solving systemic problems may give youth insight into the structural implications of social movement behaviors. For instance, an adolescent who engages in protests for a social cause may learn more about the ways in which collective action can influence policy related to social injustices. Engaged youth who gain this structural perspective may be especially inclined to view social movement as highly important compared to youth who are less involved and do not have a structural understanding of social movement. Conversely, adolescents who view social 
movement as highly important may be more inclined to seek opportunities to take part in these activities. Youth who view social movement as important based on structural justifications, or because they believe it can lead to systemic change, may be even more motivated to engage in higher levels of these behaviors compared to youth who view social movement as important for other reasons. Future research should utilize longitudinal research to further disaggregate this association.

Contrary to our expectations, adolescents' use of structural reasoning was not limited to social movement behaviors. Adolescents also considered root causes of injustice and the potential for macro-level change when reasoning about why individuals should be involved in community service and standard political activities. Structural justifications for community service and standard political involvement were associated positively with prioritization of and engagement in parallel civic behaviors. Understanding a civic behavior in terms of its potential to implement macro-level change may provide substantial motivation for youth to actively engage in that behavior. Adolescents' recognition of systemic problems (e.g., shortage of jobs that pay high enough wages to live on) may prompt them to engage in specific civic behaviors that they believe will provide an avenue for creating macro-level change to address those problems (e.g., campaign for a political candidate who will raise minimum wage). Alternatively, a critical perspective of social issues and understanding the broad impact of certain civic behaviors may be indicative of adolescents' experience with those behaviors. That is, youth civic engagement may provide unique contexts that can foster a structural perspective on civic responsibility. Thus, youth who are more civically involved may be exposed to a variety of civic 
attitudes and knowledge that may influence their understanding of social issues and civic behavior.

Hypotheses concerning adolescent community service and welfare-orientation were partially supported. The results indicated that indeed a large proportion of adolescents (43\%) emphasized a concern for the welfare of others when reasoning about volunteer work and these youths rated community service involvement as highly obligatory, important, and worthy of respect. This is consistent with previous research which found that adolescents overwhelmingly treated community service as moral in that they viewed these behaviors as highly obligatory and worthy of social praise for moral reasons (e.g., because it helps or benefits other people; Metzger \& Smetana, 2009). However, a welfare-oriented conceptualization of community service did not predict adolescents' involvement in community service activities. Instead, as noted above, structural justifications emerged as a significant predictor of adolescent community service behavior. Although the direction of this effect cannot be interpreted, previous research suggests that experiences with community service may actually prompt youth to employ a structural perspective. Yates and Youniss (1996b) found that after youth volunteered at a soup kitchen, they were more likely to reflect on broader conceptions of justice and a responsibility to fix and change society_reasoning that is consistent with a justice-orientation. Individuals who more frequently volunteer may be exposed to unique experiences that shed light on the impact their behaviors can have beyond directly helping individuals. For instance, while volunteering to feed the homeless, an individual may interact with more members of the community and come to recognize how their volunteer efforts contribute to bettering the community as a whole. Research that has examined volunteers' beliefs about civic responsibility have primarily focused on the 
importance of helping or benefitting others in need and have largely ignored how volunteers may reason about macro-level impact (e.g., National Association of Secretaries of State, 1999). However, in the current study, justice-oriented conceptualizations of community service were linked to adolescents' social and moral judgments concerning community service and to their involvement in community service activities. These findings suggest that justice-oriented reasoning is an important dimension of adolescent community service involvement.

The findings on adolescents' justice-oriented reasoning have implications for both civic education and service learning programs. Youths' budding beliefs about social movement activities are vital, yet, understudied component of civic development (Watts, Diemer, \& Voight, 2011). Civic education lessons should include discussions of not only mainstream forms of civic participation that involve working within existing social and political systems (i.e., community service and standard political acts), but also civic activities that involve working to change existing systems (i.e., social movement). Further, when youth learn about various forms of civic action in civic education classes, it may be beneficial for educators to acknowledge the different ways youth can conceptualize civic activities. For instance, when discussing community service involvement, youth may benefit from learning the ways in which volunteer work can involve directly helping individuals as well as involve contributing to society as a whole. Civic scholars have expressed concerns that service learning programs that primarily emphasize volunteerism may push youth to avoid politics and detract attention from a critical analysis of social issues (Barber, 1992; Boyte, 1991; Kahne \& Westheimer, 1996; Westheimer \& Kahne, 2004a). However, our findings suggest that youth who are more involved in community service are more likely to employ a structural perspective compared with youth who are less involved in 
community service. Similarly, adolescent involvement in more conventional forms of civic involvement, such as standard political acts (e.g., voting) was also associated with justiceoriented civic beliefs. The present study indicates that adolescents' justice-oriented reasoning has implications for engagement in various types of civic activity.

\section{Limitations and Future Directions}

The current findings should be interpreted in light of several limitations including the use of self-report data which are subject to social desirability bias. Data were cross-sectional, thus it is unclear whether adolescents' civic beliefs led to greater civic involvement or vice versa. Involvement in community service, social movement, and standard political activities expose youth to a variety of political perspectives and knowledge; these unique experiences may influence adolescents' understanding of the civic activities in which they are involved. Alternatively, adolescents with certain conceptualizations of civic involvement, specifically those with a structural understanding, may be more inclined to seek opportunities to take part in those activities. Civic developmental scientists have argued that associations between civic beliefs and civic behaviors are likely reciprocal such that civic beliefs may operate as motivation to engage in civic activities and then these civic experiences, in turn, shape adolescents' conceptualizations of the activity (Metzger \& Smetana, 2010). Future research should assess adolescents' understanding of and engagement in civic behaviors longitudinally.

A strength of the current study was that adolescents' spontaneous responses to openended questions about civic engagement were assessed, which allowed us to examine a range of adolescents' civic conceptualizations that had previously been understudied. However, inter-rater reliability for several of the content codes that were used were notably low, which may have 
decreased the likelihood of capturing associations among constructs. In addition, the ethnic and racial make-up of the present sample was primarily White which limits the generalizability of our findings. Social theorists have argued that a critical analysis of social injustice may be particularly relevant to underrepresented ethnic minority youth in America (Watts, Diemer, \& Voight, 2011) and that these groups may have different perceptions of civic engagement (Sanchez-Jankowski, 2002); future research should examine these social-cognitive processes in other samples.

\section{Conclusions}

Despite these limitations, the present findings have important implications for civic educators and civic development research. The current study is among the first to empirically investigate youth's structural understanding of various civic behaviors as it relates to their judgments for and engagement in parallel behaviors. Civic educators and service learning programs aimed at promoting civic engagement may benefit from incorporating civic discussions that foster opportunities for youth to assume a structural perspective as having a structural understanding of civic behaviors may act as an important motivator for youth civic involvement. In addition, the results emphasize the importance of considering the ways in which adolescents' qualitative understanding of civic responsibility interacts with their social and moral judgments for civic behaviors. Adolescents' justifications for their civic judgments may point to individual differences in youths' civic experiences. Findings urge researchers to continue to examine the links between facets of youth civic beliefs and civic behaviors to further elucidate the socialcognitive mechanisms that may undergird distinct forms of active citizenship. 


\section{References}

Barber, B. (1992). An aristocracy of everyone: The politics of education and the future of America. New York: Ballantine Books.

Boyte, H. C. (1991). Community service and civic education. Phi Delta Kappan, 72(10), 765767.

Flanagan, C. (2004). Volunteerism, leadership, political socialization, and civic engagement. In R. M. Lerner \& L. Steinberg (Eds.), Handbook of Adolescent Psychology (2nd ed., pp. 721745).

Flanagan, C., \& Faison, N. (2002). Youth civic development: Implications of research for social policy and programs. Social Policy Report, 15, 1-16.

Flanagan, C., Kim, T., Pykett, A., Finlay, A., Gallay, E., \& Pancer, M. (2014). Adolescents' theories about economic inequality: Why are some people poor while others are rich? Developmental Psychology, 50(11), 2512-2525.

Galston, W. A. (2007). Civic knowledge, civic education, and civic engagement: A summary of recent research. International Journal of Public Administration, 30(6-7), 623-642. doi:10.1080/01900690701215888

Gilligan, C. (1982). In a different voice. Harvard University Press. Cambridge, Massachusetts. doi: $10.2307 / 2067520$

Halik, M., \& Webley, P. (2011). Adolescents' understanding of poverty and the poor in rural Malaysia. Journal of Economic Psychology, 32, 231-239. doi:10.1016/j.joep.2009.02.006

Harrah, J., \& Friedman, M. (1991). Economic socialization in children in a midwestern American community. Journal of Economic Psychology, 11, 495-513. 
Helwig, C. (1995). Adolescents' and young adults' conceptions of civil liberties: Freedom of speech and religion. Child Development, 66(1), 152-166.

Helwig, C. (1998). Children's conceptions of fair government and freedom of speech. Child Development, 69(2), 518-531.

Helwig, C., Arnold, M. L., Tan, D., \& Boyd, D. (2003). Chinese adolescents' reasoning about democratic and authority-based decision making in peer, family, and school contexts. Child Development, 74(3), 783-800.

Hyman, J. (2002). Exploring social capital and civic engagement to create a framework of community building. Applied Developmental Science, 6, 196- 202.

Jost, J. T., Federico, C. M., \& Napier, J. L. (2009). Political ideology: Its structure, functions, and elective affinities. Annual review of psychology, 60, 307-337.

Kahne, J., \& Westheimer, J. (1996). In the service of what? Phi Delta Kappan, 77, 592-599.

Killen, M. (2007). Children's social and moral reasoning about exclusion. Current Directions in Psychological Science, 16(1), 32-36.

Killen, M., \& Malti, T. (2015). Moral judgments and emotions in contexts of peer exclusion and victimization. In Advances in child development and behavior (1st ed., Vol. 48, pp. 249276). Elsevier Inc. doi:10.1016/bs.acdb.2014.11.007

McIntosh, H., \& Youniss, J. (2010). Toward a political theory of political socialization of youth. In L. R. Sherrod, J. Torney-Purta, \& C. A. Flanagan (Eds.), Handbook of research on civic engagement in youth (pp. 23-41). Hoboken, NJ: John Wiley \& Sons Inc. doi:10.1002/9780470767603.ch1 
Metzger, A. (2007). Domain-specific judgments of civic and political engagement in late adolescence: Associations with adolescent activity involvement (Doctoral dissertation, University of Rochester).

Metzger, A., \& Ferris, K. (2013). Adolescents' domain-specific judgments about different forms of civic involvement: Variations by age and gender. Journal of Adolescence, 36(3), 529538. doi:10.1016/j.adolescence.2013.03.003

Metzger, A., Oosterhoff, B., Palmer, C., \& Ferris, K. (2014). Dimensions of citizenship: Associations among adolescents' sociopolitical values and civic judgments. Political Science \& Politics, 47(2), 443-448.

Metzger, A., \& Smetana, J. G. (2009). Adolescent civic and political engagement: Associations between domain-specific judgments and behavior. Child Development, 80(2), 433-41. doi:10.1111/j.1467-8624.2009.01270.x

Metzger, A., \& Smetana, J. G. (2010). Social cognitive development and adolescent civic engagement. In L. R. Sherrod, J. Torney-Purta, \& C. A. Flanagan (Eds.), Handbook of Research on Civic Engagement in Youth (pp. 221-248). Hoboken, NJ: John Wiley \& Sons.

Nucci, L. P. (2001). Education in the moral domain. Cambridge, UK: Cambridge University Press.

Nucci, L. P., \& Gingo, M. (2010). The development of moral reasoning. The Wiley-Blackwell handbook of childhood cognitive development, 22, (pp. 420-445). Malden, MA: WileyBlackwell.

Roberts, F. \& Robinson, J.D. (2004). Interobserver agreement on first-stage conversation analytic transcription. Human Communication Research, 30(3), 376-410. 
Sanchez-Jankowski, M. (2002). Minority youth and civic engagement: The impact of group relations. Applied Developmental Science, 6, 237-245.

Sherrod, L. R., \& Lauckhardt, J. (2009). The development of citizenship. In R. M. Lerner \& L. Steinberg (Eds.), Handbook of adolescent psychology (3rd ed., Vol. 2, pp. 372-407). New York: Wiley \& Sons.

Sherrod, L., Torney-Purta, J., \& Flanagan, C. (Eds.). (2010). Handbook of research on civic engagement in youth. Hoboken, N.J.: John Wiley \& Sons.

Smetana, J. G. (1985). Preschool children's conceptions of transgressions: Effects of varying moral and conventional domain-related attributes. Developmental Psychology, 21(1), 18.

Smetana, J. G. (2006). Social-cognitive domain theory: Consistencies and variations in children's moral and social judgments. In M. Killen \& J. G. Smetana (Eds.), Handbook of Moral Development (pp. 119-153). Mahwah, NJ: Erlbaum.

Smetana, J. G., \& Braeges, J. L. (1990). The development of toddlers' moral and conventional judgments. Merrill-Palmer Quarterly, 36(3), 329-346.

Smetana, J. G., Schlagman, N., \& Adams, P. W. (1993). Preschool children's judgments about hypothetical and actual transgressions. Child Development, 64(1), 202-214.

Smetana, J. G., \& Turiel, E. (2008). Moral development during adolescence. Blackwell handbook of adolescence, 8, 247.

Smetana, J. G., \& Villalobos, M. (2009). Social cognitive development in adolescence. In R. M. Lerner, \& L. Steinberg (Eds.), Handbook of adolescent psychology: Individual bases of adolescent development (3rd ed.) (pp. 187-228). Hoboken, NJ, US: Wiley \& Sons Inc. 
Snell, P. (2010). Emerging adult civic and political disengagement: A longitudinal analysis of lack of involvement with politics. Journal of Adolescent Research, 25(2), 258-287.

Syvertsen, A. K., Wray-Lake, L., Flanagan, C. A., Osgood, D. W., \& Briddell, L. (2011). Thirty year trends in U.S. adolescents' civic engagement: A story of changing participation and educational differences. Journal of Research on Adolescence, 21(3), 586-594. doi:10.1111/j.1532-7795.2010.00706.x

Tocqueville, A. (1848/1966). Democracy in America. NY: Harper \& Row.

Torney-Purta, J., Lehmann, R., Oswald, H., \& Schulz, W. (2001). Citizenship and education in twenty-eight countries: Civic knowledge and engagement at age fourteen. Amsterdam: International Association for the Evaluation of Educational Achievement.

Turiel, E. (2002). The culture of morality: Social development, context, and conflict. New York, NY, US: Cambridge University Press.

Turiel, E. (2008). Thought about actions in social domains: Morality, social conventions, and social interactions. Cognitive Development, 23(1), 136-154. doi:10.1016/j.cogdev.2007.04.001

Wainryb, C. (1991). Understanding differences in moral judgments: The role of informational assumptions. Child Development, 62(4), 840-851.

Walker, T. (2000). The service/politics split: Rethinking service to teach political engagement. Political Science \& Politics, 33(3), 646-649.

Walker, Tobi. (2002). Service as a pathway to political participation: What research tells us. Applied Developmental Science, 6(4), 183-188. 
Watts, R. J., Diemer, M. A., \& Voight, A. M. (2011). Critical consciousness: Current status and future directions. In C. A. Flanagan \& B. D. Christens (Eds.), New Directions for Child and Adolescent Development (pp. 43-57). doi:10.1002/cd

Watts, R. J., \& Flanagan, C. (2007). Pushing the envelope on youth civic engagement: A developmental and liberation psychology perspective. Journal of Community Psychology, 35(6), 779-792. doi:10.1002/jcop.20178

Westheimer, J., \& Kahne, J. (2004a). Educating the "good" citizen: Political choices and pedagogical goals. Political Science \& Politics, 37(02), 241-247.

Westheimer, J., \& Kahne, J. (2004b). What kind of citizen? The politics of educating for democracy. American Educational Research Journal, 41(2), 237-269. doi:10.3102/00028312041002237

Wray-Lake, L., \& Syvertsen, A. K. (2011). The developmental roots of social responsibility in childhood and adolescence. In C. A. Flanagan \& B. D. Christens (Eds.), Youth civic development: Work at the cutting edge. New Directions for Child and Adolescent Development, 134, 11-25.

Yates, M., \& Youniss, J. (1996a). A developmental perspective on community service in adolescence. Social Development, 5(1), 85-111.

Yates, M., \& Youniss, J. (1996b). Community service and political-moral identity in adolescents. Journal of Research on Adolescence, 6(3), 271-284.

Youniss, J., McLellan, J. A., \& Yates, M. (1997). What we know about engendering civic identity. The American Behavioral Scientist, 40(5), 620-631.

doi:10.1177/0002764297040005008 
Table 1a. Civic Justification Code Categories for Protest, Definitions, Kappa Coefficients, and Frequencies

\begin{tabular}{|c|c|c|c|}
\hline Category & Criterion statements and example & $\kappa$ & $\mathrm{n}(\%)$ \\
\hline \multicolumn{4}{|c|}{ Q1. Why should people take part in political protest or rally? } \\
\hline Structural & $\begin{array}{l}\text { Recognition of problems within political system or } \\
\text { describes how protest can help implement systemic } \\
\text { level change (e.g., to help change or solve a problem } \\
\text { with laws that may be unconstitutional). }\end{array}$ & .63 & $133(18.4)$ \\
\hline Voice beliefs & $\begin{array}{l}\text { Describes how protest allows citizens to voice their } \\
\text { opinions and express what they believe (e.g., so } \\
\text { people can hear what you believe). }\end{array}$ & .72 & $150(20.8)$ \\
\hline Personal & $\begin{array}{l}\text { Describes an individual's ambivalence toward } \\
\text { protesting; individuals have a choice in whether or not } \\
\text { they partake (e.g., it should be up to the person to } \\
\text { decide). }\end{array}$ & .72 & $106(14.7)$ \\
\hline Duty & $\begin{array}{l}\text { Describes a duty or obligation to act upon one's } \\
\text { personal beliefs (e.g., if you feel strongly about a } \\
\text { cause, you have to stand up for what you believe in). }\end{array}$ & .74 & $172(23.9)$ \\
\hline Rights as a citizen & $\begin{array}{l}\text { Describes self-interested actions of citizenship, or the } \\
\text { ways that protesting is a privilege for citizens (e.g., } \\
\text { it's every American's right to protest). }\end{array}$ & .77 & $38(5.3)$ \\
\hline $\begin{array}{l}\text { Influence } \\
\text { others/gather } \\
\text { together }\end{array}$ & $\begin{array}{l}\text { Describes people coming together with a goal of } \\
\text { changing others' opinions or joining together with } \\
\text { like-minded individuals (e.g., protesting allows people } \\
\text { to get together with others who share their beliefs). }\end{array}$ & .65 & $42(5.8)$ \\
\hline Shouldn't & $\begin{array}{l}\text { States that people should not protest; language that } \\
\text { describes protesting as unfavorable (e.g., people } \\
\text { shouldn't protest because...). }\end{array}$ & .82 & $124(17.2)$ \\
\hline Random & $\begin{array}{l}\text { Answers that do not fit in a previous category or } \\
\text { statements that are deemed uncodeable. }\end{array}$ & .39 & $80(11.1)$ \\
\hline
\end{tabular}


Table 1b. Civic Justification Code Categories for Volunteering, Definitions, Kappa Coefficients, and Frequencies

\begin{tabular}{llll}
\hline Category & Criterion statements and example & $\kappa$ & $\mathrm{n}(\%)$
\end{tabular}

\section{Q2. Why should people volunteer to help feed the homeless?}

Welfare

Statements in which the welfare of others is taken into

$.62323(44.8)$

consideration. Describes the recognition that others have needs and that people have an obligation to fulfill the needs of others (e.g., so they don't die and to take care of them; These are human beings that deserve help).

Structural

Expressing reasons why individuals are homeless based on societal inequalities or situations beyond the individual's control (root causes) or statements that describe global or community-focused changes rather than one's obligation to help protect an individual's welfare (e.g., It is not always their faults that are in that situation, for example the elderly who run out of money paying for a Medication and can no longer pay rent; Because it would help our community and benefit our economy).

Fairness:

Describes that helping the homeless will ensure the

Perceived

Reciprocity volunteer is helped if ever in the same circumstances or describes the "golden rule" or recognition of the social contract (e.g., I am also a firm believer in the golden rule, and if you would want someone to feed you if you were homeless, you should help feed the homeless too

Fairness: Inequity Obligation
Describes an obligation to help based on unequal $.8173(10.1)$ distribution of resources/goods/abilities. Statements describe how one party has more and another party has less and due to this inequality, the party that has more has an obligation to help contribute to those with 
less (e.g., They should because those people have

literally nothing, and I think people who have the income to should definitely help).

\begin{tabular}{llll}
\hline Category & Criterion statements and example & $\kappa$ & $\mathrm{n}(\%)$ \\
\hline
\end{tabular}

Cont. Q2. Why should people volunteer to help feed the homeless?

Good boy/girl

Describes how helping others is a kind or good thing $\quad .66$

$166(23)$

to do (e.g., it is a kind, generous, and good thing to $d o)$.

Description of

Describes characteristics of homeless individuals or

$.55 \quad 83(11.5)$

homelessness

obstacles that individuals may encounter as a result of being homeless (e.g., homeless people have nothing, they do not have any food to eat).

Personal benefit

Statements about the volunteer gaining something from helping feed the homeless. Any form of personal benefit (e.g., it might make you feel good inside, like you accomplished something. Also you could get volunteer hours, or community service hours).

Personal

Describes individuals' ambivalence toward

prerogative volunteering. Individuals have a choice in whether or not they partake (e.g., I think that this is completely up to the person).

Internal causes

Describes reasons why individuals are homeless based on personal disposition or actions (e.g., we shouldn't feed the homeless because it's their fault they're homeless...they're just too lazy to work)

Little effort

Describes how volunteering does not require much effort (e.g., it will not take much out of your day to spend a little time helping, so you should do it). 
Shouldn't

States that people should not volunteer; language that

$.73 \quad 35(4.9)$ describes volunteering as unfavorable (e.g., people shouldn't volunteer because...).

Random

Answers that do not fit in a previous category or statements that are deemed uncodeable.

Table 1c. Civic Justification Code Categories for Voting, Definitions, Kappa Coefficients, and Frequencies

\begin{tabular}{|c|c|c|c|}
\hline Category & Criterion statements and example & $\kappa$ & $\mathrm{n}(\%)$ \\
\hline \multicolumn{4}{|c|}{ Q3. Why should people vote in political elections? } \\
\hline Structural & $\begin{array}{l}\text { Describes how voting can lead to macro-level change; } \\
\text { describes influencing the future of government, } \\
\text { country, or society (e.g., people should vote because it } \\
\text { will determine how the country is run). }\end{array}$ & .62 & $97(13.5)$ \\
\hline Voice beliefs & $\begin{array}{l}\text { Describes how voting allows citizens to voice their } \\
\text { opinions and express their beliefs (e.g., to show what } \\
\text { you think is right). }\end{array}$ & .80 & $166(23)$ \\
\hline Can't complain & $\begin{array}{l}\text { Describes how people cannot complain about the } \\
\text { outcome of elections if they do not vote (e.g., if you } \\
\text { don't vote, you can't be mad about who gets elected). }\end{array}$ & .96 & $104(14.4)$ \\
\hline Candidate specific & $\begin{array}{l}\text { Describes how voting allows you to endorse a } \\
\text { particular candidate; reasons based on a preference for } \\
\text { a specific candidate (e.g., you should vote to pick the } \\
\text { candidate you like the best). }\end{array}$ & .75 & $141(19.6)$ \\
\hline $\begin{array}{l}\text { Citizen's } \\
\text { Obligation }\end{array}$ & $\begin{array}{l}\text { Describes a compelling feeling to contribute to the } \\
\text { common good of society or an obligation to take part } \\
\text { as a citizen (e.g., people have died for your right to } \\
\text { vote, so you have a responsibility to exercise that } \\
\text { right). }\end{array}$ & .93 & $57(7.9)$ \\
\hline
\end{tabular}


Right as a citizen $\quad$ Describes self-interested actions of citizenship, or the $\quad .83 \quad 68$ (9.4) ways that protesting is a privilege for citizens (e.g., it's every American's right to vote).

Personal $\quad$ Describes an individual's ambivalence toward voting; $\quad .73 \quad 71(9.8)$ individuals have a choice in whether or not they partake (e.g., it should be up to the person to decide).

$\begin{array}{llll}\text { Every vote counts } & \text { Describes how an individual vote can make a } & .88 & 55(7.6)\end{array}$ difference in the outcome of an election (e.g., your vote could make a difference in who wins the election).

$\begin{array}{llll}\text { Description } & \text { Describes the voting process (e.g., voting helps us } & .12 & 63 \text { (8.7) }\end{array}$ decide who our leader will be).

Shouldn't

States that people should not vote; language that $.01 \quad 22(3.1)$ describes voting as unfavorable (e.g., people shouldn't vote because it doesn't make a difference).

Random Answers that do not fit in a previous category or $.46 \quad 83(11.5)$ statements that are deemed uncodeable. 
Table 2. Correlations among civic judgments and civic behavior for social movement (SM), community service (CS), and standard political (SP) involvement

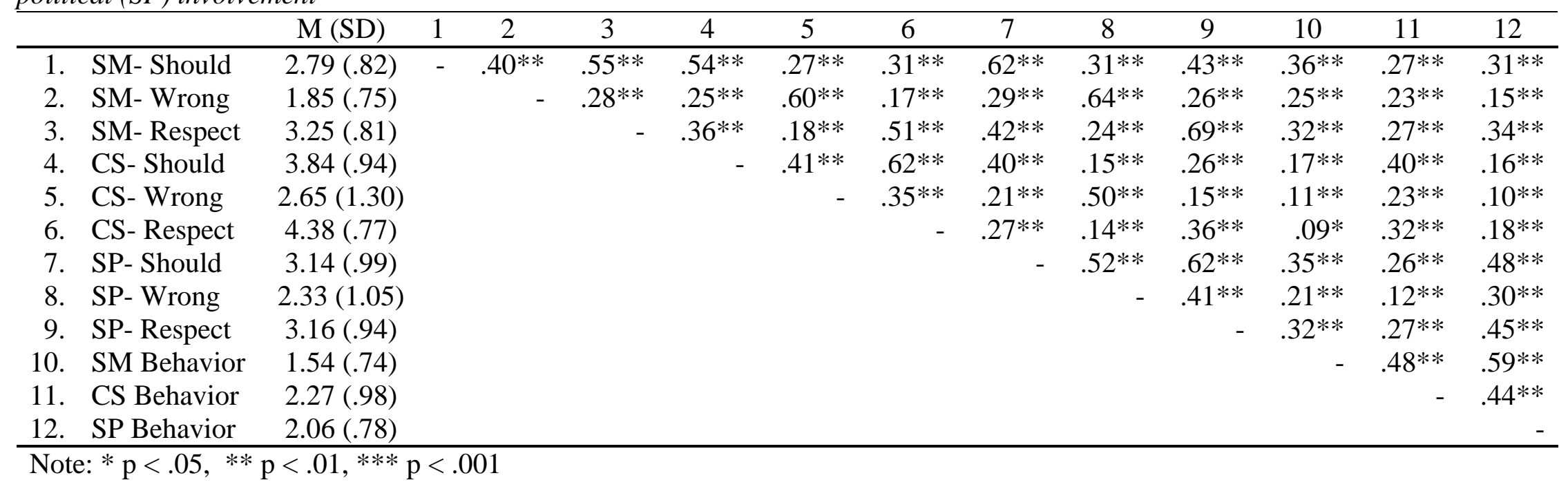

Table 3. Correlations among Social Movement Judgments, Justifications, and Adolescent Demographics

\begin{tabular}{|c|c|c|c|c|c|c|c|c|c|}
\hline & Judgments & Structural & $\begin{array}{l}\text { Voice } \\
\text { beliefs }\end{array}$ & Duty & Personal & Should not & Gender & Age & $\begin{array}{c}\text { Parent } \\
\text { Education }\end{array}$ \\
\hline Judgments & - & $.15^{* * *}$ & $.10 *$ & $.17 * * *$ & $-.22 * * *$ & $-.18 * * *$ & $.13 * *$ & .00 & $.12 *$ \\
\hline Structural & & - & $-.10 * *$ & -.07 & $-.16 * *$ & $-.12 * *$ & -.02 & -.04 & $.10 * *$ \\
\hline Voice beliefs & & & - & $-.18 * *$ & $-.12 * *$ & $-.15 * *$ & $.10 * *$ & .01 & .04 \\
\hline Duty & & & & - & $-.11 * *$ & $-.13 * *$ & .04 & .05 & $.08 *$ \\
\hline Personal & & & & & - & $-.18 * *$ & .00 & -.01 & .05 \\
\hline Should not & & & & & & - & .03 & -.02 & -.02 \\
\hline Gender & & & & & & & - & -.07 & .04 \\
\hline Age & & & & & & & & - & $-.09 *$ \\
\hline Parent & & & & & & & & & \\
\hline education & & & & & & & & & - \\
\hline
\end{tabular}

Note: $* \mathrm{p}<.05, * * \mathrm{p}<.01, * * * \mathrm{p}<.001$ 
Table 4. Correlations among Community Service Judgments, Justifications, and Adolescent Demographics

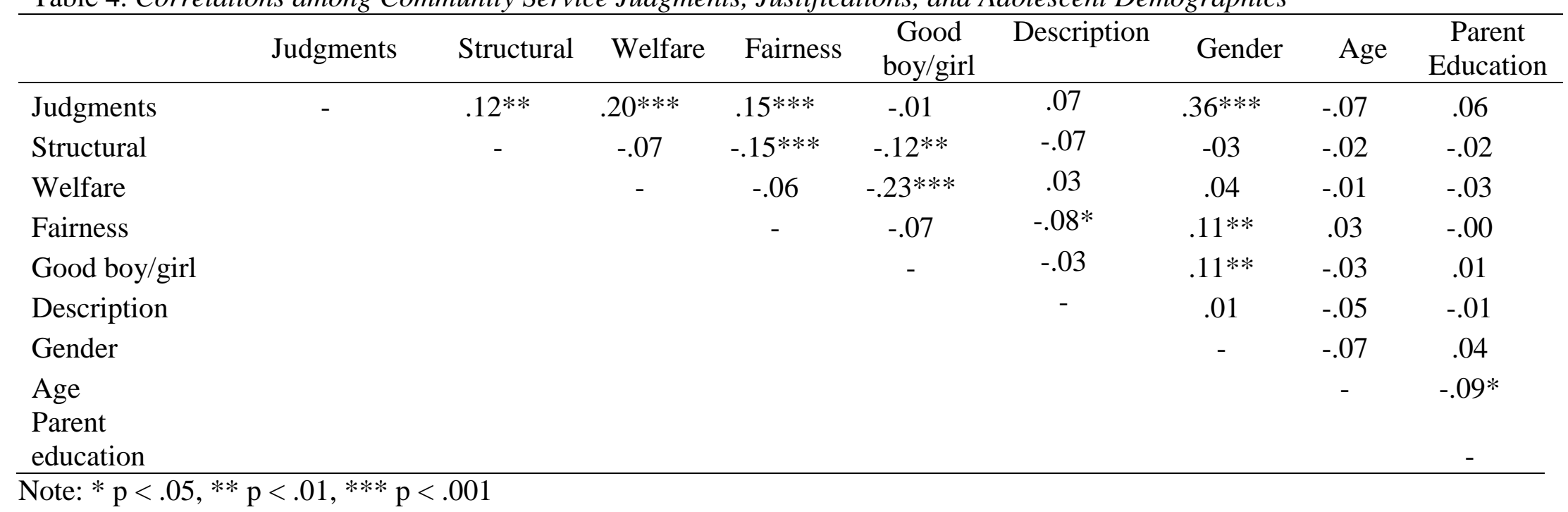

Table 5. Correlations among Standard Political Judgments, Justifications, and Adolescent Demographics

\begin{tabular}{|c|c|c|c|c|c|c|c|c|}
\hline & Judgments & Structural & $\begin{array}{l}\text { Voice } \\
\text { beliefs }\end{array}$ & $\begin{array}{c}\text { Can't } \\
\text { complain }\end{array}$ & $\begin{array}{l}\text { Candidate } \\
\text { specific }\end{array}$ & Gender & Age & $\begin{array}{c}\text { Parent } \\
\text { Education }\end{array}$ \\
\hline Judgments & - & $.11 * *$ & $.16^{* * *}$ & $.18 * * *$ & .05 & .03 & .06 & $.25 * * *$ \\
\hline Structural & & - & $-.10 * *$ & -.02 & $-.08 *$ & .04 & -.04 & .06 \\
\hline Voice beliefs & & & - & .05 & $-.16 * * *$ & $.13 * * *$ & .03 & .08 \\
\hline Can’t complain & & & & - & $-.16 * * *$ & .07 & .05 & .03 \\
\hline Candidate Specific & & & & & - & $-.08 *$ & .04 & -.09 \\
\hline Gender & & & & & & - & -.07 & .04 \\
\hline Age & & & & & & & - & $-.10 *$ \\
\hline Parent education & & & & & & & & - \\
\hline
\end{tabular}




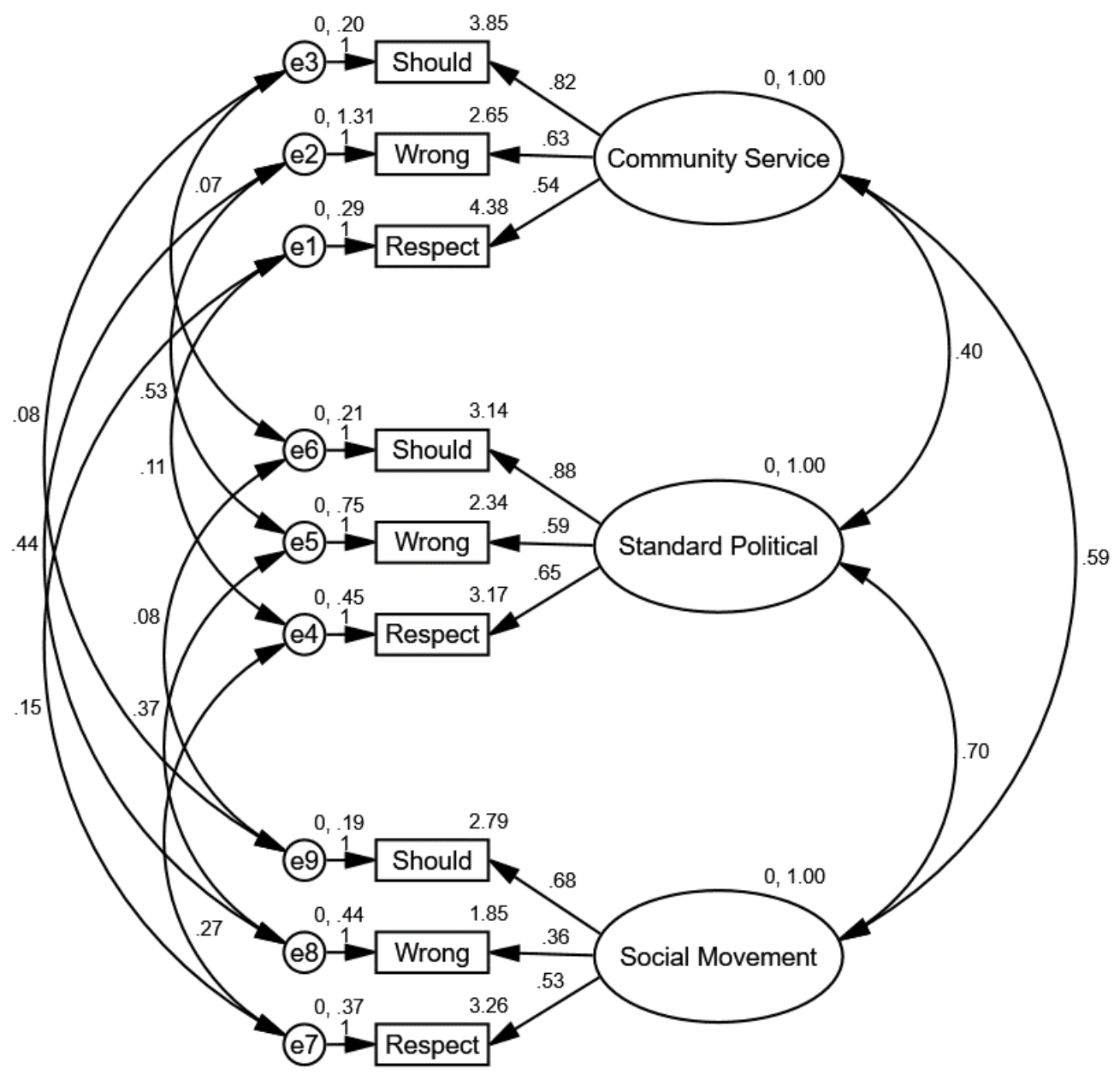

Figure 1. Measurement model for latent variables representing adolescent civic judgments Note. All estimates are standardized. $\chi^{2} / \mathrm{df}=1.80, \mathrm{CFI}=0.99, \mathrm{RMSEA}=0.03$ 


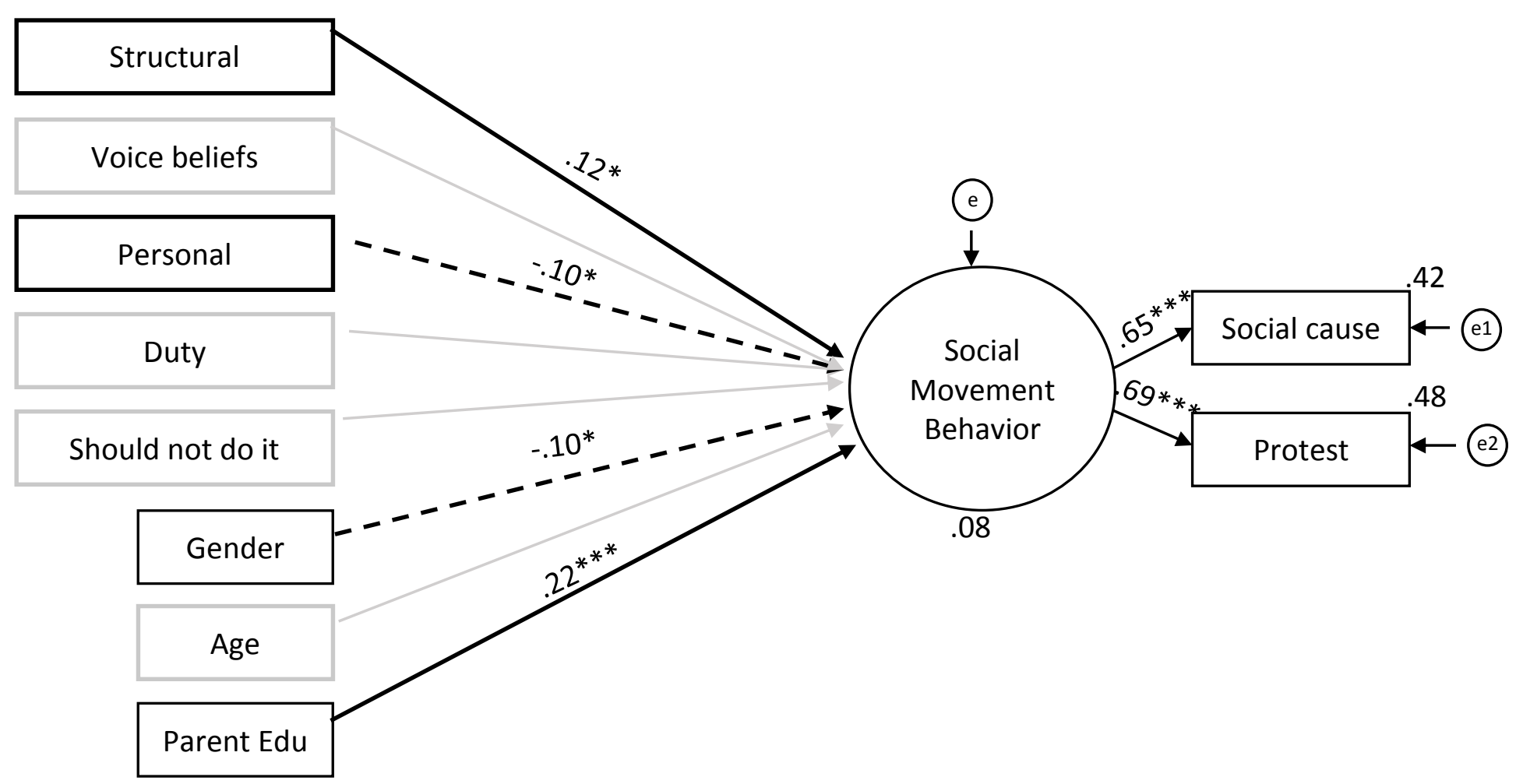

Figure 2. Civic Justifications for social movement involvement as predictors of adolescent social movement behavior (trimmed model)

Note. Estimates are standardized coefficients. $\chi^{2} / \mathrm{df}=2.02, \mathrm{CFI}=.96, \mathrm{RMSEA}=.04 .{ }^{*} p<.05, * * p<.01, * * * p<.001$ 


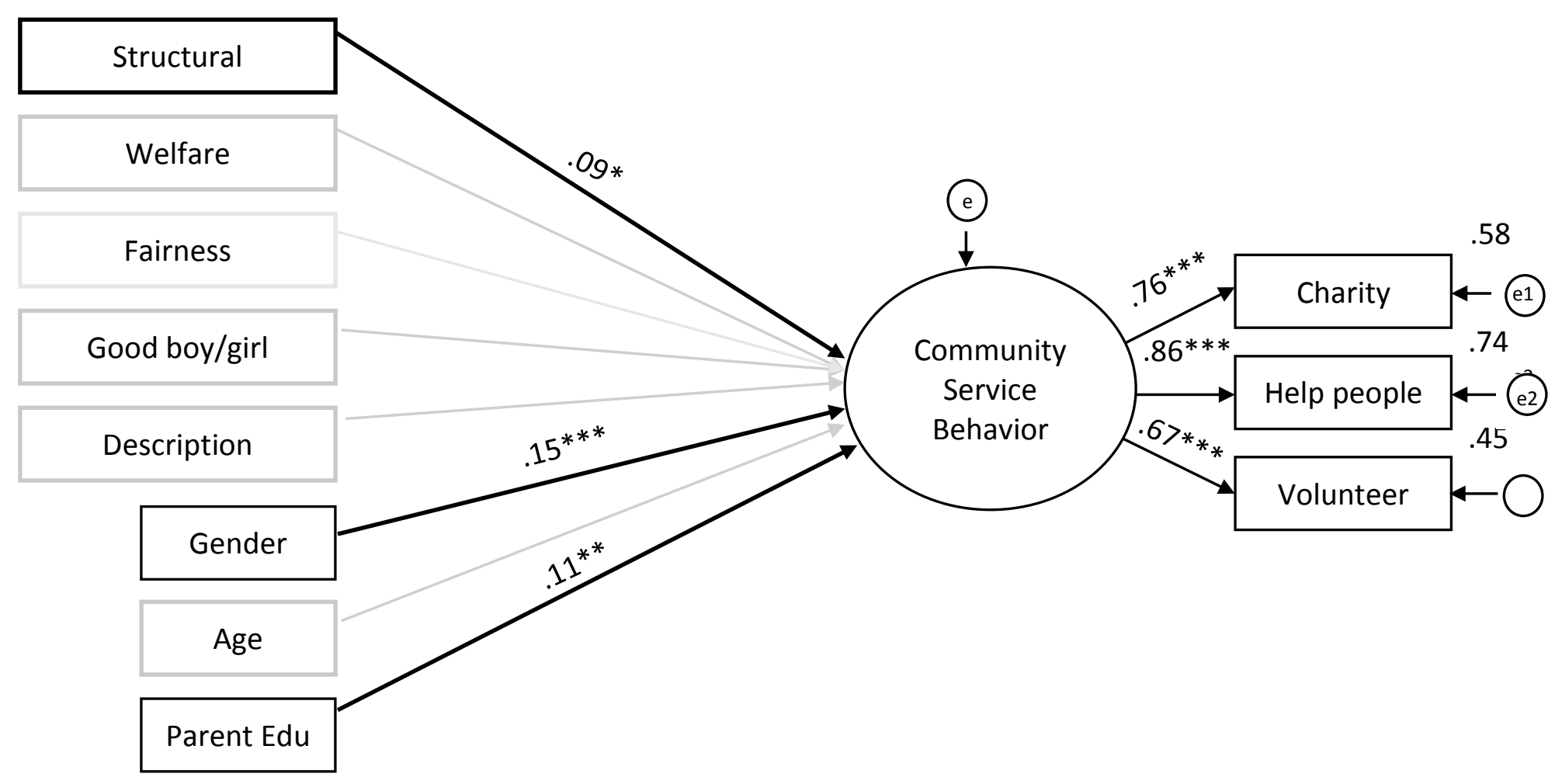

Figure 3. Civic Justifications for community service involvement as predictors of adolescent community service behavior (trimmed model)

Note. Estimates are standardized coefficients. $\chi^{2} / \mathrm{df}=1.48, \mathrm{CFI}=.99, \mathrm{RMSEA}=.03 . * p<.05, * * p<.01, * * * p<.001$ 


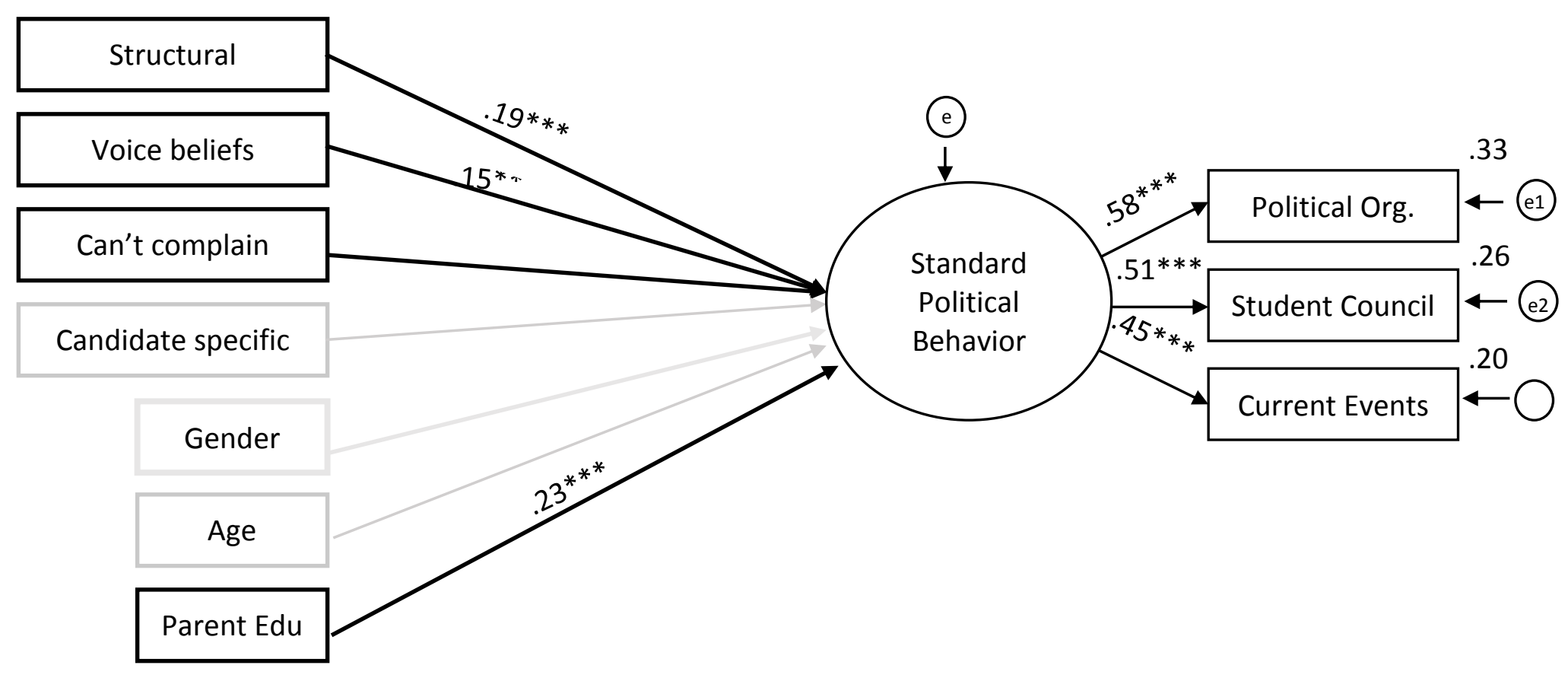

Figure 4. Civic Justifications for standard political involvement as predictors of adolescent standard political behavior (trimmed model)

Note. Estimates are standardized coefficients. $\chi^{2} / \mathrm{df}=1.98, \mathrm{CFI}=.94, \mathrm{RMSEA}=.04 .{ }^{*} p<.05, * * p<.01, * * * p<.001$ 
1. What gender are you?

\section{Appendix A \\ Demographics}

¡Male FFemale

2. How old are you? (years) What is your birthday? (Month/Day/Year)

3. What is your grade in school? $6^{\text {th }} \quad 7^{\text {th }} 8^{\text {th }} 9^{\text {th }} \quad 10^{\text {th }} 11^{\text {th }} \quad 12^{\text {th }}$

4. School grades (average for the year):

\rceil Mostly A's

†Some A's some B's

$\nmid$ Mostly B's

† Some B's some C's

$\nmid$ Mostly C's

† Some C's some D's

$\nmid$ Mostly D's or lower

5. What is your ethnicity (check all that apply)?
\rceil African-American/Black
\rceil Asian-American/Pacific Islander
Hispanic/Latino
$\lceil$ Caucasian/White
Native American
POther (describe)

6. Who currently lives in your home (check all that apply)?

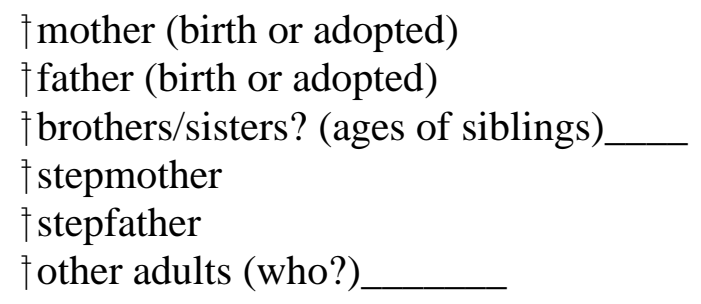

7. What is the highest level of schooling your 8 . What is the highest level of schooling your mother (or female guardian) completed? father (or male guardian) completed? 
$\nmid$ Completed $8^{\text {th }}$ grade

\rceil Completed high school

\rceil Completed college

\rceil Graduate degree (doctor, lawyer, $\mathrm{PhD}$ )

$\nmid$ Don’t know or unsure \rceil Completed $8^{\text {th }}$ grade

\rceil Completed high school

\rceil Completed college

$\lceil$ Graduate degree (doctor, lawyer, $\mathrm{PhD}$ )

$\nmid$ Don't know or unsure

Appendix B

Free-response Assessment of Adolescent Civic Justifications

There are many different reasons why people might take part in different political or community activities.

-Think about the reason that YOU think best explains why people should take part in that activity.

-OR if you think people should NOT do the activity, write why you think they shouldn't. -Feel free to write as many reasons as you want.

-please write CLEARLY!!!

WHY SHOULD PEOPLE VOLUNTEER TO HELP FEED THE HOMELESS?

(or write why you think they should not)

WHY SHOULD PEOPLE VOTE IN POLITICAL ELECTIONS? (or write why you think they should not)

WHY SHOULD PEOPLE TAKE PART IN A POLITICAL PROTEST OR RALLY? (or write why you think they should not) 


\section{Appendix C \\ Adolescent Civic Judgments}

Adolescents' Prioritization (sociomoral) Judgments

How much do you think people $S H O U L D$ do the following activities?

How wrong is it NOT to do the following activities?

How much would you respect someone who did the following activities?

Community Service Items

3. Volunteers for a fundraiser aiding victims of a natural disaster

5. Volunteers to help the people in your community

11. Volunteers to help feed the homeless people

15. Volunteers to help disabled students at your school

\section{Social Movement Items}

1. Take part in a political protest or rally

4. Write to a newspaper, magazine, blog, or website about a social or political issue

8. Work to help change a law that they disagree with

16. Distribute a petition for a cause

\section{Standard Political Activity Items}

6. Join a political party

10. Work on a political campaign

13. Keep up with current events and politics

14. Know who their elected representatives and leaders are

17. Vote in a political election 


\section{Appendix D \\ Adolescent Civic Involvement}

Organized Activities In an average month, how often do you do the following activities OR work with the following groups. For each activity you are involved in, estimate the number of HOURS EACH MONTH you commit to the activity.

\begin{tabular}{|c|c|c|c|c|c|}
\hline How often do you.... & Never & $\begin{array}{l}\text { Not } \\
\text { often }\end{array}$ & Some & $\begin{array}{l}\text { Quite } \\
\text { often }\end{array}$ & $\begin{array}{l}\text { Very } \\
\text { often }\end{array}$ \\
\hline \multicolumn{6}{|l|}{ Community Service Items } \\
\hline 8. work for charity to collect money for a social cause & 1 & 2 & 3 & 4 & 5 \\
\hline $\begin{array}{l}\text { 12. volunteer to help poor, sick, or disabled people in } \\
\text { your community }\end{array}$ & 1 & 2 & 3 & 4 & 5 \\
\hline $\begin{array}{l}\text { 15. volunteer to clean up your neighborhood, school, } \\
\text { or community }\end{array}$ & 1 & 2 & 3 & 4 & 5 \\
\hline \multicolumn{6}{|l|}{ Social Movement Item } \\
\hline 16. take part in a political rally or protest & 1 & 2 & 3 & 4 & 5 \\
\hline $\begin{array}{l}\text { 5. participate with an organization focused around a } \\
\text { political or social cause }\end{array}$ & 1 & 2 & 3 & 4 & 5 \\
\hline \multicolumn{6}{|l|}{ Standard Political Items } \\
\hline $\begin{array}{l}\text { 1. participate in an organization affiliated with a } \\
\text { political party or union }\end{array}$ & 1 & 2 & 3 & 4 & 5 \\
\hline $\begin{array}{l}\text { 10. take part in student council or hold school political } \\
\text { positions }\end{array}$ & 1 & 2 & 3 & 4 & 5 \\
\hline $\begin{array}{l}\text { 18. Know what's going on in the news and about } \\
\text { political events }\end{array}$ & 1 & 2 & 3 & 4 & 5 \\
\hline
\end{tabular}


Appendix E

Summary of Measures for Each Construct

\begin{tabular}{|c|c|c|c|}
\hline Construct & Social movement & Community service & Standard political \\
\hline$\frac{\text { Civic Justifications: }}{\text { Why should people... }}$ & $\begin{array}{l}\text { take part in a political } \\
\text { protest or rally? } \\
\text { - Structural } \\
\text { - Voice beliefs } \\
\text { - Personal } \\
\text { - Duty }\end{array}$ & $\begin{array}{l}\text { volunteer to help feed the } \\
\text { homeless? } \\
\text { - Structural } \\
\text { - Welfare } \\
\text { - Fairness } \\
\text { - Good boy/girl } \\
\text { - Description }\end{array}$ & $\begin{array}{l}\text { vote in a political election? } \\
\text { - Structural } \\
\text { - Voice beliefs } \\
\text { - Can't complain } \\
\text { - Candidate specific }\end{array}$ \\
\hline $\begin{array}{l}\text { Civic Judgments: } \\
\text { How much do you think } \\
\text { people should do the } \\
\text { following? } \\
\text { How wrong is it not to do } \\
\text { the following? } \\
\text { How much would you } \\
\text { respect someone who did } \\
\text { the following? }\end{array}$ & $\begin{array}{l}\text { - Take part in a political } \\
\text { protest or rally } \\
\text { - Write to a newspaper, } \\
\text { magazine, blog, or website } \\
\text { about a social or political } \\
\text { issue } \\
\text { - Work to help change a law } \\
\text { that they disagree with } \\
\text { - Distribute a petition for a } \\
\text { cause }\end{array}$ & $\begin{array}{l}\text { - Volunteers for a fundraiser } \\
\text { aiding victims of a natural } \\
\text { disaster } \\
\text { - Volunteers to help the } \\
\text { people in your community } \\
\text { - Volunteers to help feed the } \\
\text { homeless people } \\
\text { - Volunteers to help disabled } \\
\text { students at your school }\end{array}$ & $\begin{array}{l}\text { - Join a political party } \\
\text { - Work on a political campaign } \\
\text { - Keep up with current events } \\
\text { and politics } \\
\text { - Know who their elected } \\
\text { representatives and leaders are } \\
\text { - Vote in a political election }\end{array}$ \\
\hline$\frac{\text { Civic Involvement: }}{\text { How often do you... }}$ & $\begin{array}{l}\text { - Take part in a political } \\
\text { protest or rally? } \\
\text { - Participate with an } \\
\text { organization focused } \\
\text { around a political or social } \\
\text { cause? }\end{array}$ & $\begin{array}{l}\text { - Work for charity to collect } \\
\text { money for a social cause? } \\
\text { - Volunteer to help poor, } \\
\text { sick, or disabled people in } \\
\text { your community? } \\
\text { - Volunteer to clean up your } \\
\text { neighborhood, school, or } \\
\text { community? }\end{array}$ & $\begin{array}{l}\text { - Participate in an organization } \\
\text { affiliated with a political party } \\
\text { or union? } \\
\text { - Take part in student council or } \\
\text { hold school political positions? } \\
\text { - Know what's going on in the } \\
\text { news and about political } \\
\text { events? }\end{array}$ \\
\hline
\end{tabular}




\section{Appendix F}

\section{Trimmed Table of Civic Justifications}

Table 6. Civic Justifications Utilized in Current Study: Definitions, Kappa Coefficients, and Frequencies Separated by Civic Activity

\begin{tabular}{llll}
\hline Category & Criterion statements and example & $\kappa$ & $\mathrm{n}(\%)$ \\
\hline
\end{tabular}

\section{Q1. Why should people take part in political protest or rally?}

Structural Recognition of problems within political system or describes how protest can help implement systemic level change (e.g., to help change or solve a problem with laws that may be unconstitutional).

Voice beliefs $\quad$ Describes how protest allows citizens to voice their opinions and express what they believe (e.g., so people can hear what you believe).

Personal Describes an individual's ambivalence toward $.72106(14.7)$ protesting; individuals have a choice in whether or not they partake (e.g., it should be up to the person to decide).

Duty Describes a duty or obligation to act upon one's personal beliefs (e.g., if you feel strongly about a cause, you have to stand up for what you believe in).

\section{Q2. Why should people volunteer to help feed the homeless?}

Welfare

Statements in which the welfare of others is taken into .62

$323(44.8)$ consideration. Describes the recognition that others have needs and that people have an obligation to fulfill the needs of others (e.g., so they don't die and to take care of them; These are human beings that deserve help). 
Structural

Fairness:

Perceived

Reciprocity
Expressing reasons why individuals are homeless

.70

based on societal inequalities or situations beyond the individual's control or statements that describe global or community-focused changes rather than one's obligation to help protect an individual's welfare (e.g., It is not always their faults that are in the situation that they for example the elderly who run out of money paying for a Medication and can no longer pay rent; Because it would help our community and benefit our economy).

Describes that helping the homeless will ensure the

Fairness: Inequity Obligation

Good boy/girl

Description of homelessness volunteer is helped if ever in the same circumstances or describes the "golden rule" or recognition of the social contract (e.g., I am also a firm believer in the golden rule, and if you would want someone to feed you if you were homeless, you should help feed the homeless too
Describes an obligation to help based on unequal distribution of resources/goods/abilities. Statements describe how one party has more and another party has less and due to this inequality, the party that has more has an obligation to help contribute to those with less (e.g., They should because those people have literally nothing, and I think people who have the income to should definitely help).

Describes how helping others is a kind or good thing to do (e.g., it is a kind, generous, and good thing to $d o)$.

Describes characteristics of homeless individuals or $.55 \quad 83(11.5)$

$.8173(10.1)$

$.66166(23)$
$.82 \quad 85(11.8)$ obstacles that individuals may encounter as a result of being homeless (e.g., homeless people have nothing, they do not have any food to eat). 


\section{Q3. Why should people vote in political elections?}

Structural

Describes how voting can lead to macro-level change

$.6297(13.5)$ describes influencing the future of government, country, or society (e.g., people should vote because it will determine how the country is run).

Voice beliefs

Describes how voting allows citizens to voice their opinions and express their beliefs (e.g., to show what you think is right).

Can't complain Describes how people cannot complain about the $.96104(14.4)$ outcome of elections if they do not vote (e.g., if you don't vote, you can't be mad about who gets elected).

Candidate specific Describes how voting allows you to endorse a $.75 \quad 141(19.6)$ particular candidate; reasons based on a preference for a specific candidate (e.g., you should vote to pick the candidate you like the best). 


\section{Appendix G \\ Extended Literature Review and Methods}

A democracy’s success relies heavily on civically engaged citizens (Tocqueville, 1966; Snell, 2010). In the interest of enhancing civic engagement, researchers have argued that it is imperative to uncover the developmental processes that underlie active citizenship (Flanagan, \& Faison, 2002). Citizens of the United States possess both rights and duties (Hyman, 2002; Sherrod \& Laukhardt, 2009), and previous research has focused on how youth view their rights as a citizen (Helwig, Arnold, Tan, \& Boyd, 2003; Helwig, 1995; Helwig, 1998). In contrast, civic beliefs concern individuals' conceptual understanding of citizenship obligations. Such beliefs are vital, yet, understudied components of civic engagement that can shed light on civic developmental processes and may be important predictors of adult civic engagement (Metzger \& Smetana, 2010). Civic development researchers have only recently begun to investigate how youth think about their duties as citizens, that is, how individuals reason about the importance and obligatory nature of civic involvement (Metzger \& Ferris, 2013; Metzger, Oosterhoff, Palmer, \& Ferris, 2014; Metzger \& Smetana, 2009).

Civic involvement is a multifaceted construct that encompasses a wide range of civic, community, and political activities and behaviors (Galston, 2007; Metzger \& Smetana, 2010). Certain forms of civic involvement entail directly helping individuals in need (e.g., volunteering to the feed the homeless) whereas other civic activities involve solving problems at a systemic level through social movement (e.g., engaging in political protest). Scholars theorize that there are different types of citizens who have distinct civic beliefs and are likely to engage in specific forms of civic action (Westheimer \& Kahne, 2004). For instance, justice-oriented citizens value 
equality and reason that is important to critically assess the causes of social injustices; they emphasize the importance of implementing macro-level change through collective action (social movement). In contrast, other types of citizens may be more concerned with the welfare of individuals in need and choose to take part in community service. However, there has been little empirical investigation into the presence of these different orientations (welfare vs. justice) during adolescence, or how these divergent ways of viewing civic involvement map onto adolescents' evaluations of and engagement in different civic activities.

The proposed study aims to further elucidate the mechanisms underlying civic development by investigating different facets of adolescents' reasoning about civic engagement and examining how these beliefs are associated with adolescents' involvement in various civic behaviors. Specifically, this study investigates how adolescents coordinate distinctions between welfare-oriented reasoning and justice-oriented reasoning in their evaluations of different civic behaviors (i.e., civic judgments), and examines whether a welfare-oriented or justice-oriented conceptualization of civic engagement affects associations between adolescents' civic involvement and civic judgments. Distinct patterns are expected to emerge across adolescents' civic beliefs and behaviors that may reflect developmental origins of different types of citizens (i.e., welfare-oriented and justice-oriented citizens).

\section{Civic Engagement}

Civic engagement is a multifaceted construct. Traditionally, political scientists used the term civic engagement to refer strictly to standard political involvement (e.g., voting in a political election; Walker, 2000). Developmental psychologists have broadened the definition of civic engagement to include voluntary activities intended to serve others or the community (e.g., 
community service) and "social-cause" political activities (e.g., protesting for a cause; TorneyPurta, Lehmann, Oswald, \& Schulz, 2001). Similarly, many scholars posit that political activities and community service are distinct constructs (Kahne \& Westheimer, 1996; Walker, 2000, 2002). This approach is consistent with research from the social domain perspective, which demonstrates that adolescents distinguish between community service, social movement, and standard political activities in both their judgments and justifications of civic engagement (Metzger \& Smetana, 2009).

Although all forms of civic action involve prosocial behaviors aimed at helping others, bettering one's community, or benefiting greater societal institutions, different civic activities may offer unique opportunities to positively affect individuals and to contribute to communities and institutions. For youth, engagement in these activities may differentially influence civic development. For instance, community service typically involves directly helping individuals in need (e.g., feeding the homeless). In contrast, social movement and standard political acts provide more indirect avenues of contributing to society. Social movement typically involves leading and organizing action to influence social and political policy (e.g., protesting; Kahne \& Westheimer, 1996). Social movement activists tend to focus on the causes of a social or political issue and this structural perspective leads them to take collective action toward community betterment (Watts, Diemer, \& Voight, 2011; Westheimer \& Kahne, 2004). While social movement involves working to change existing systems, standard political activity is considered a more mainstream form of civic action whereby individuals typically work within existing social and political systems (e.g., voting). 
Engagement in community service, social movement, and standard political activities expose youth to a variety of political and civic attitudes and knowledge. Certain forms of involvement may differentially foster conceptions of welfare (concern for others in need) and justice-oriented beliefs (structural perspective and emphasis on fairness). In addition to encompassing a wide range of civic behaviors, developmental researchers have also conceptualized civic engagement as a multifaceted construct that includes civic behavior, skills, beliefs, and values. Developmental research that looks at the intersection of these different facets of civic development during adolescence may provide essential information on the origins of individual civic identity. For instance, adolescents' views of different types of civic behaviors (i.e., their civic beliefs) are theorized to be developmental antecedents of specific forms of civic involvement in adulthood (Metzger \& Smetana, 2010).

\section{Civic Beliefs in Adolescence}

Researchers have only recently begun to engage in empirical research concerning adolescents' budding conceptualizations of civic engagement (Metzger \& Ferris, 2013; Metzger, Oosterhoff, Palmer, \& Ferris, 2014; Metzger \& Smetana, 2009). Adolescence is a developmental period marked by increasing social responsibility, identity exploration, and dramatic cognitive maturation that allows teens to engage in complex abstract reasoning (Smetana \& Villalobos, 2009). With increased cognitive abilities, adolescents can reflect on their experiences, take the perspective of others, and consider the potential impact of their civic behaviors on individuals and on society (Sherrod, Torney-Purta, Flanagan, 2010). These cognitive advancements may facilitate the development of adolescents' civic identity. Thus, adolescence is the ideal developmental period for investigating individuals' developing civic reasoning, as adolescents 
are accumulating civic knowledge and experiences and are forming more individualized beliefs. These foundational components of civic identity may play an important role in defining the types of citizens adolescents will become upon entering adulthood (Youniss, McLellan, \& Yates, 1997).

Social domain theory provides a useful rubric for examining adolescents' civic conceptualizations by assessing how teens reason about different forms of civic engagement (Metzger \& Smetana, 2010). According to social domain theory, individuals interpret their social worlds from different domains of social knowledge and draw on these domains when reasoning about different types of social behaviors and events (Smetana, 2006). Research from this perspective has identified three social knowledge systems relevant to civic development: moral, conventional, and personal domains (Metzger \& Smetana, 2010).

The moral domain pertains to issues of welfare, justice/fairness, and rights. Moral judgments are obligatory, universal, and not dependent on authority or context. In contrast, the conventional domain refers to context-specific, arbitrary, alterable, agreed-upon regulations; conventions are shared behaviors that have meaning based on societal expectations and social norms (Smetana, 2006). These conventions govern social interactions within a specific cultural context (Turiel, 2002). The personal domain differs from both moral and conventional domains in that personal issues are not subject to morality or social regulation; personal issues pertain to the self and are viewed as matters of personal prerogative (Smetana, 2006).

Previous research has focused on how individuals apply domain-specific reasoning to issues that concern violating one's welfare, justice, or rights (e.g. Killen, 2007; Smetana, 1985; Smetana \& Braeges, 1990; Smetana, Schlagman, \& Adams, 1993). In contrast, civic behaviors 
represent prosocial activities, that is, issues that concern promoting positive or helping behaviors. In order to assess adolescents' domain-specific reasoning about different civic activities, researchers have examined adolescents' domain-specific justifications for why people should engage in civic behaviors (Metzger \& Smetana, 2009). Moral justifications concern welfare and fairness whereas conventional justifications concern social norms and authority. Personal justifications involve viewing the issue or behavior as a matter of personal choice, lying outside conventional jurisdiction or moral concern (Smetana, 2006). Researchers have also measured adolescents' civic judgments, that is, views of obligation towards and social praiseworthiness of various civic behaviors (Metzger \& Ferris, 2013; Metzger, Oosterhoff, Palmer, \& Ferris, 2014; Metzger \& Smetana, 2009; Metzger, 2007). For instance, adolescents' views of obligation are assessed through ratings of how wrong they think it is for people NOT to engage in various civic behaviors. Adolescents also rate the degree to which they think people should take part in various civic behaviors. To assess social praiseworthiness, adolescents rate how much they would respect someone who takes part in various civic behaviors (Metzger \& Smetana, 2009).

Adolescents systematically apply domain-specific justifications and judgments to different civic behaviors (Metzger \& Ferris, 2014; Metzger \& Smetana, 2009). Adolescents viewed community service as obligatory and worthy of social praise for moral reasons (e.g., because it helps other people) whereas standard political activity was viewed as more obligatory for conventional reasons (e.g., important for things to run smoothly). Participants used personal justifications (e.g., up to the person) most for social movement involvement compared to community service and standard political activity. Thus, social movement involvement was rated as less obligatory, important, and worthy of respect compared to community service and standard 
political activities. However, a large percentage of adolescents (16\%) also used moral justifications for social movement, which was significantly larger than the amount of moral justifications given for standard political activity (5\%). Similarly, many adolescents also applied conventional justifications for social movement behaviors (23\%), which was significantly larger than the amount of conventional justifications given for community service (9\%). The authors interpreted this pattern of responses as indicating that youth were conceptualizing social movement involvement as a multifaceted behavior. Multifaceted behaviors entail overlapping domains (i.e., conflicting concerns with morality, conventions, and personal issues) and often contribute to developmental and contextual variability (Smetana, 2006). These findings suggest that adolescents understand that community service, social movement, and standard political involvement constitute conceptually and behaviorally distinct forms of civic action. However, although adolescents reason about each civic activity differently, there is also considerable individual variability that warrants further investigation, particularly in terms of adolescents' understanding of social movement (Metzger \& Smetana, 2009).

Previous research examining adolescents' justifications for civic involvement utilized a forced-choice measure of civic justifications in which only domain-specific justifications were assessed. Thus, researchers may not have captured the full range of justifications that adolescents utilize when reasoning about civic involvement. Furthermore, moral justifications of civic behaviors were assessed with a single item (helps or benefits other people), which prevented researchers from exploring distinctions between different types of moral reasoning including welfare and fairness. 
Welfare- vs. justice-oriented reasoning. Researchers have long recognized care, or concern for others' welfare, and justice as distinct principles (Gilligan, 1982; Wray-Lake \& Syvertsen, 2011). Understanding how individuals reason about others' welfare and justice is vital to advancing research concerning social development (Killen \& Malti, 2015). Moreover, conceptualizations of welfare and justice may have different implications for civic development. Scholars posit that some citizens are oriented toward compassion for individuals in need (i.e., welfare-oriented morality) whereas others emphasize fairness and root causes of social injustices (i.e., justice-oriented citizens; Westheimer \& Kahne, 2004). Previous research from a social domain perspective has primarily collapsed individuals' justifications pertaining to concepts of harm/welfare and fairness into a moral category (Turiel, 2008). However, there has been little empirical investigation into the potential unique correlates of these different facets of moral reasoning. For instance, different aspects of morality may be differentially applied to certain forms of civic engagement.

Prior research (Metzger \& Smetana, 2009) demonstrated that adolescents view community service involvement as moral in that it is highly obligatory and worthy of respect for moral reasons, with moral justifications focusing on helping or benefitting others. Given the overt prosocial nature of community service, adolescents may attribute the importance of community service to the direct effect it can have on individuals' welfare. Thus, moral reasons that specifically reflect welfare concern may be particularly important for adolescents' beliefs about community service.

In contrast, adolescents' moral reasoning about other forms of civic involvement may entail different facets of the moral domain. Civic and political scholars posit that some citizens 
focus on justice and equality for entities beyond the individual level (Watts \& Flanagan, 2007; Westheimer \& Kahne, 2004). Citizens may apply this critical stance to civic engagement through collective action aimed at social change (Watts, Diemer, \& Voight, 2011). This is consistent with Westheimer and Kahne's (2004) justice-oriented citizens, who are theorized to engage in social movement behaviors in order to help bring about change to address social injustices in a civic or political system. Other scholars similarly suggest that reasoning about fairness and equality may play an important role in challenging injustice and taking social action (Wray-Lake \& Syvertsen, 2011). Thus, fairness-oriented moral justifications may be more relevant to adolescents' reasoning about social movement compared to other civic activities. The use of welfare-oriented vs. fairness-oriented moral justifications may reflect different ways of conceptualizing citizenship.

In addition to focusing on fairness and equality, justice-oriented citizens emphasize the importance of critically assessing the root causes of injustices and employing a structural perspective (Westheimer \& Kahne, 2004). Justice-oriented citizens are theorized to focus on how they can improve society or a community by making systemic level changes. For example, when confronted by a homeless person, a justice-oriented citizen may look beyond this particular individual's needs and instead examine the context in which the homeless individual's circumstances arose (Kahne \& Westheimer, 1996). In order to strategize a course of action, the justice-oriented citizen may draw on informational assumptions, or beliefs about political, economic, or social structures that caused the problem (Westheimer \& Kahn, 2004; Wainryb, 1991). With this knowledge, the justice oriented person would then focus on civic action aimed at implementing macro-level changes to the institutional system responsible for homelessness. 
Informational assumptions are descriptive beliefs that represent individuals' factual understanding of their social environment. Previous research demonstrates that informational assumptions are associated with individuals' moral judgments. For example, individuals' positive or negative judgments about abortion are connected to informational assumptions about when life begins (Wainryb, 1991). Similarly, adolescents may hold factual beliefs about individuals and social-political systems that influence how they reason about civic duty. When reasoning about civic engagement, teenagers may emphasize descriptive beliefs that reflect a structural perspective. That is, they may describe the root causes of social problems (e.g., systematic inequalities in job opportunities) when reasoning about homelessness. Furthermore, when justifying civic engagement, some adolescents may describe the importance of civic involvement for influencing social and political systems as opposed to how civic involvement can directly affect the welfare of single individuals. Based on their focus on systematic causes and macro-level change, adolescents who apply structural justifications may be especially inclined to prioritize social movement involvement, that is, judge social movement as obligatory, important, and worthy of respect.

Age. In order to advance research on civic development, it is important to uncover agerelated changes in how adolescents coordinate social knowledge systems when reasoning about civic behaviors. As previously discussed, the moral domain broadly encompasses issues that concern welfare, fairness, and rights; these facets of morality may follow distinct developmental trajectories. Moral development during childhood and adolescence is marked by changes in conceptualizations of human welfare and justice (Nucci \& Gingo, 2010). Children’s moral reasoning tends to focus on concrete notions of welfare (e.g., hitting another person; Nucci, 
2001). However, with age, children's moral reasoning broadens as they more consistently incorporate an understanding of fairness and equality. During adolescence, teenagers consolidate an understanding of equality and equity and develop a more comprehensive concept of justice (Nucci \& Gingo, 2010; Smetana \& Turiel, 2008). With bourgeoning cognitive capabilities, adolescents become increasingly prepared to apply their conceptualizations of justice more universally; that is, teens can generalize morality beyond the individual level to more abstract phenomena like social groups (Smetana \& Turiel, 2008). Thus, when reasoning about the importance of civic participation, early adolescents may be more likely to emphasize the welfare of single individuals whereas late adolescents may be more likely to emphasize more broadly applied ideas of justice.

In addition to a potential shift in welfare- and fairness-oriented moral reasoning, an increase in cognitive abilities during adolescence may also contribute to age differences in adolescents' use of structural justifications. Research demonstrates age-related differences in adolescents' reasoning about social issues (wealth and poverty) with late adolescents demonstrating an awareness of structural problems in the system that could be responsible for economic inequality such as, economic downturn (Halik \& Webley, 2011; Harrah \& Friedman, 1991; Jost et al., 2009). Flanagan et al. (2014) found that late adolescents were more likely to reference societal causes (e.g., discrimination) as their first explanation of why some people in the United States are poor, whereas early adolescents were more likely to emphasize individual or dispositional factors when reasoning about poverty. Given the increased capacity for abstract reasoning during adolescence, these findings suggest that compared to early adolescents, late 
adolescents may be more able to look beyond the individual level and reflect on the systemic causes underlying social issues.

Taken together, the literature on moral development which shows age-related advancements in moral reasoning and studies that show age differences in adolescent reasoning about social issues suggest that late adolescents may be more likely to possess civic beliefs that align with Westheimer and Kahne's (2004) justice-oriented citizen. That is, when reasoning about civic action, late adolescents may be more cognitively prepared to incorporate an understanding of justice, to reason about the macro-level impact of civic involvement, and to consider systemic causes of social issues. Thus, with age, adolescents may be more likely to utilize fairness-oriented moral justifications as well as structural justifications when reasoning about why people should take part in various civic activities.

\section{Associations between Civic Beliefs and Civic Behavior}

Conceptualizations of civic duties are central to adolescents' civic development in that adolescents' reasoning about citizenship has been theorized to antecede future decision to participate in certain forms of civic action (Metzger \& Smetana, 2010). Moreover, involvement in civic activities is associated with the ways teenagers think about their civic responsibilities. Research indicates that adolescents' civic beliefs systematically align with their involvement in civic activities. That is, compared to less engaged adolescents, civically engaged adolescents are more likely to prioritize civic involvement (i.e., view civic involvement as obligatory and worthy of respect; Metzger \& Smetana, 2009). Researchers found that adolescent civic behaviors were associated with parallel civic beliefs such that community service involvement was associated with prioritizing community service activity whereas political involvement was positively 
associated with judgments concerning standard political and social movement activity. Furthermore, compared to less involved adolescents, highly involved adolescents were less likely to use personal justifications when reasoning about why people should take part in civic activities (Metzger \& Smetana, 2009).

This previous research demonstrates how adolescent engagement in different civic behaviors is systemically associated with their conceptualizations of civic responsibilities. However, this study utilized a forced-choice measure of civic justifications, which limited researchers from exploring distinctions between welfare and fairness moral justifications. This measure was also limited to domain-specific justifications; thus researchers did not assess how adolescents may utilize structural justifications (critically assessing root causes of social issues) when reasoning about civic involvement. There has been little empirical investigation into how adolescent civic behaviors are differentially associated with welfare-oriented and justice-oriented reasoning.

Although studies demonstrate that civic involvement is associated with more positive judgments about corresponding civic behaviors (i.e. in terms of obligation and social praise), it may also be associated with qualitatively different understandings of civic involvement. That is, youth civic activity may be linked to different views of their relationship to society and unique conceptualizations concerning the importance of civic participation. For instance, research that has evaluated service-learning programs demonstrate that compared to students involved in community service, students involved in social movement behaviors aimed at social justice were more likely to emphasize root causes (i.e., structural justifications) when reasoning about social problems (e.g., poverty is caused by a shortage of jobs that pay high enough wages to support 
one's self; Westheimer \& Kahne, 2004). These students were also more likely to discuss the need for collective, rather than individualistic forms of social action. In contrast, other studies have found that individuals involved in community service tend to focus on the potential for one to help others (i.e., take action individually as opposed to collectively), and are often motivated by compassion and a concern for other individuals (Yates \& Youniss, 1996a). Thus, justiceoriented reasoning (fairness and structural justifications) may be associated with social movement involvement whereas welfare-oriented moral reasoning may be associated with community service involvement. The current study will assess how civic behaviors (community service, social movement, and standard political activity) differentially predict the use of welfare- vs. justice-oriented justifications.

Researchers have often treated judgments and justifications as distinct components of social and moral reasoning (Turiel, 2002). However, these dimensions of thought may also be interactive such that the association between behaviors and judgments may be amplified in the presence of different justifications. A qualitative assessment of adolescent civic justifications is vital because it allows researchers to explore not just whether individuals think civic involvement is important (civic judgments), but why they think various civic behaviors are important (civic justifications). Distinct civic justifications may intersect with adolescents' civic behaviors to differentially predict how adolescents prioritize various civic activities.

Although prior research indicates that community service involvement is associated with positive judgments concerning community service, a qualitative assessment of adolescent civic reasoning may reveal individual differences in this association. Adolescents' reflective essays written before and after volunteering at a soup kitchen show increased levels of transcendence. 
That is, after youth volunteered, they were more likely to perspective-take, recognize inequity between themselves and homeless people, and reflect on broader conceptions of justice and a responsibility to fix and change society (Yates \& Youniss, 1996b). This increase in transcendence reflects a shift towards beliefs that align with Westheimer and Kahne's justiceoriented citizen who are theorized to value fairness and equality and to employ a structural perspective which leads them to take collective action (social movement). In contrast, researchers have also demonstrated that youth engagement in community service is associated with a greater concern for individuals in need (Westheimer \& Kahne, 2004; Yates \& Youniss, 1996). These qualitative shifts in reasoning about civic obligation may affect the degree to which involvement is associated with adolescents' beliefs or prioritization of different forms of civic involvement. For instance, if involvement in community service is associated with a justiceorientation (structural perspective and emphasis on fairness), these volunteers may be less likely to prioritize community service involvement whereas community service volunteers who have a greater concern for the welfare of individuals (i.e., welfare-orientation) may be especially inclined to prioritize community service involvement.

\section{The Proposed Study}

The way adolescents think about and view their duties as citizens is an important component of their developing civic identity and may ultimately influence the type of citizen they become later in life (Metzger \& Smetana, 2010). While helpful for elucidating adolescents' civic conceptualizations, previous studies that used civic judgments combined with forcedchoice measures of domain-specific justifications did not account for the full range of adolescents' qualitative understanding of civic engagement. To add to previous literature on 
adolescent civic reasoning, a free-response methodology will be used to assess a broader range of youth justifications for civic involvement as well as to examine finer distinctions between different types of moral reasoning. Furthermore, the proposed study will examine the extent to which distinct conceptualizations of civic engagement map onto adolescents' prioritization of and engagement in different forms of civic activities.

The first research aim is to investigate how adolescents reason about different forms of civic engagement. It is anticipated that variation across justifications will reveal that adolescents systematically apply different justifications to specific types of civic activity. Adolescents are expected to apply welfare-oriented justifications to civic activities which involve directly helping individuals in need (community service) and to apply justice-oriented justifications (structural and fairness) to civic action aimed at systemic level change and collective action (social movement). Age differences in adolescents' civic reasoning will also be explored.

The second research aim is to investigate how adolescents' civic justifications differentially predict prioritization of various civic activities. Scholars theorize that there are different types of citizens characterized by distinct beliefs about civic responsibility and who are likely to engage in specific forms of civic action (Westheimer \& Kahne, 2004). However, prior research that empirically examined how adolescents' civic justifications align with their evaluations of community service, social movement, and standard political involvement was limited to a set number of domain-specific justifications (Metzger \& Smetana, 2009). Thus, it remains unclear how adolescents' welfare- vs. justice-oriented reasoning about civic involvement map onto their judgments of different civic activities. Examining how adolescents coordinate welfare- and justice-oriented reasoning with their evaluations of different civic 
behaviors will provide new insight into the developmental mechanisms underlying moral and social development.

It has been theorized that engagement in different civic activities may encourage adolescents to prioritize parallel forms of civic action (Metzger \& Smetana, 2010). However, civic involvement may not influence all adolescents in the same way, that is, there may be individual differences concerning circumstances in which youth civic engagement is associated with positive evaluations of civic behaviors. This positive association may depend on how different civic behaviors are related to individuals' reasoning (justifications) about social issues and civic responsibility. Investigating this cognitive process is key to understanding how adolescents develop into different types of active citizens. The third research aim is to identify how associations between civic involvement and civic judgments vary as a function of civic justifications. For instance, prior research suggests that community service involvement will be associated with prioritizing community service, however, this association may be stronger for adolescents who attribute the importance of community service to its impact on individuals' welfare and weaker for adolescents who utilize justice-oriented justifications (fairness and structural).

\section{Research Questions and Hypotheses}

Research Question 1. Do adolescents' civic justifications vary for different types of civic activity? Do civic justifications vary by age?

Hypothesis 1. Compared to fairness-oriented moral and structural justifications, adolescents will justify volunteering to feed the homeless using more welfare-oriented moral justifications. 
Hypothesis 2. When justifying why people should take part in political protest or rally, adolescents will use more structural and fairness-oriented moral reasoning compared to welfare-oriented moral reasoning.

Hypothesis 3. Early adolescents will be more likely to use welfare-oriented moral justifications whereas late adolescents will be more likely to use structural and fairnessoriented moral justifications.

Research Question 2. How are adolescents' civic justifications for all forms of civic engagement associated with their civic judgments?

Hypothesis 4. It is hypothesized that moral justifications pertaining to welfare across all forms of civic activity will be positively associated with judgments about community service (i.e., viewing community service as more important, obligatory, and worthy of respect).

Hypothesis 5. Structural justifications and moral justifications pertaining to fairness across all forms of civic activity will be positively associated with judgments about social movement.

Research Question 3. How are adolescents' civic beliefs associated with their engagement in civic activities?

Hypothesis 6. It is hypothesized that different forms of adolescent civic involvement will predict adolescents' prioritization judgments and civic justifications. More specifically, a. Adolescents' civic behaviors will align with their judgments about parallel civic activities (e.g. community service involvement will be associated with positive judgments about community service) 
$b$. Involvement in community service will be associated with welfare-oriented moral justifications

$c$. Involvement in social movement will be associated with fairness-oriented moral justifications

$d$. Involvement in social movement will be associated with structural justifications Hypothesis 7. Associations between civic behaviors and civic judgments will vary by different types of justifications. More specifically,

$a$. The association between community service involvement and community service judgments will be stronger for adolescents who give welfare-oriented justifications compared to those who do not give welfare-oriented justifications. $b$. The association between social movement involvement and social movement judgments will be stronger for adolescents who give structural and fairnessoriented moral justifications (i.e., justice-oriented justifications) compared to adolescents who do not give justice-oriented justifications.

\section{Method}

\section{Participants}


Participants were 743 adolescents $\left(M_{\text {age }}=15.87, S D=1.28\right.$, range $=13-20$ years, $90 \%$

Caucasian, 55.6\% female) from a small rural town $(n=376)$ and a mid-sized University city $(n=$ 367) in the Appalachian region of the United States.

\section{Procedure}

All students at the high school were offered the opportunity for participation.

Recruitment and survey administration took place in social studies classrooms. Only students who assented and obtained parental consent were administered a survey. The surveys were administered by research team members who remained present to answer questions about the survey and to provide instructions. Participants who completed the survey were eligible to win a randomly drawn cash prize ranging from $\$ 25$ to $\$ 100$.

\section{Civic Coding}

Participants were asked three free response questions that assessed adolescents' justifications for why people should take part in specific forms of civic action. They were instructed to provide reasons that they think best explains why people should or should not participate in a political protest or rally (social movement), volunteer to feed the homeless (community service), and vote in political elections (standard political). Participants were instructed to write down the 1-2 most important reasons for participating in the civic activity.

Coding Process. The content of adolescents' justifications for why people should take part in volunteering to feed the homeless, political protest, and voting was coded for themes related to domains of social reasoning and other sociomoral concepts. Two coders, the author and a reliability coder, analyzed participants' civic justifications. A training manual was created in conjunction with training meetings to help establish reliability between the two coders. 
Training consisted of two coders separately coding one set of 25 cases per week and then meeting to exchange notes which were used to update the coding manual. Interrater reliability was considered adequate when kappa coefficients on jointly coded cases reached .60 (Cohen, 1960; Lance, 2006). After acceptable reliability was established, the author independently coded all of the cases and the reliability coder coded $25 \%$ of the cases.

Content Coding. The coding system was designed to assess the substance of participants' written statements within a free-response question task and assign specific codes based on the types of information reported in those statements. A central assumption in this approach is that participants' written statements reflect individuals' beliefs about why individuals should be engaged in three different civic behaviors (protesting, volunteering, and voting). After reading each answer comprised of multiple statements, coders assessed whether the statements contained any material relevant to the codes. A single codable statement began when a new idea was introduced and ended when the idea was concluded or when punctuation indicated the end of a sentence. Each statement within an individual's response received only one code. However, participants could respond with multiple statements for each question, thus individuals could receive multiple codes. Participants received score of either 0 (absent) or 1 (present) for each coding category.

The current coding scheme was developed based on a subset of responses, theory, previous research (Helwig, 1998; Helwig et al., 2003), and discussions with experts in the field. Twelve separate codes will be utilized for the proposed study ( 5 codes for responses to volunteering, 1 codes for responses to protest, 1 codes for responses to voting; Appendix H). A welfare-oriented justification was defined as a concern for the welfare of others and an obligation 
to help individuals in need (e.g., we should help feed the homeless because it's wrong to let humans starve; 1 code for volunteering). A structural justification was defined as describing the root causes of an issue or describing macro- or systemic level change ( 2 for volunteering, 1 for protest, 1 for voting).

Two codes were created that assessed fairness-oriented moral justifications for adolescent responses concerning why people should volunteer to feed the homeless. Statements describing an obligation to help based on unequal distribution of resources or abilities were coded as fairness- inequity obligation. Statements describing how helping homeless individuals will ensure someone will help the volunteer if they were in that position were coded as fairnessperceived reciprocity. In addition, two codes for volunteering captured adolescents' structural reasoning. Statements describing that people should volunteer because being homeless is the result of societal inequalities or other external forces, rather than individuals' disposition (i.e., it is not their fault) were coded as structural- root causes. These statements described the root causes of homelessness (e.g., economy, discrimination). Statements describing macro- or community-level changes, as opposed to protecting an individual's welfare, were coded as structural- community change. Fairness-oriented moral justifications and structural justifications were assumed to be indicators of justice-oriented civic reasoning. Justice-oriented justifications regarding why people should protest as well as why people should vote refer to the code structural: fix problems/influence government. This code, applied both to responses for protest and voting, is defined as describing macro-level change and fixing problems (e.g., change policy, influence future of the government). 


\section{Questionnaire Measures}

The questionnaire will assess adolescents' qualitative justifications as described above, prioritization judgments, as well as involvement in community service, social movement, and standard political activity. The questionnaire also includes demographic information (for questionnaire measures, see Appendices A-D).

Demographics. Adolescents reported their age, gender, and parental education.

\section{Civic Prioritization Judgments.}

Should Scale. Participants rated whether individuals "should" take part in 4 volunteering items, 4 social movement items, and 5 standard political activity items. Responses were measured with a 5-point Likert scale ranging from 1 (doesn't matter) to 5 (definitely should). Higher ratings indicate stronger feelings that people should be engaged in each civic activity. See Appendix B for items separated by civic activity.

Obligation Scale (wrong). Adolescents' obligatory attitudes about civic involvement was assessed using 13 items from a 17 item questionnaire asking participants to rate how "wrong" it is not to take part in 4 volunteering items, 4 social movement items, and 5 standard political activity items. Responses were measured with a 5-point Likert scale ranging from 1 (not at all wrong) to 5 (very wrong). Higher scores indicate stronger feelings of obligation for each civic activity.

Respect Scale. Participants rated the praiseworthiness of 13 civic activities. Adolescents were asked to rate how much they would respect someone who takes part in 4 volunteering items, 4 social movement items, and 5 standard political activity items. Responses were 
measured with a 5-point Likert scale ranging from 1 (none at all) to 5 (a lot). Higher ratings indicate stronger beliefs that involvement in the civic activity is worthy of social praise (respect).

Civic Involvement. Adolescent civic behaviors were measured using 8 items from a 25 item questionnaire assessing general civic involvement (see Appendix B). These items measure involvement in volunteering ( 3 items), social movement ( 2 items), and standard political activity (3 items). Items assessed current involvement over the past 30 days. Responses will be given on a 5-point Likert scale ranging from 1 (never) to 5 (very often). 


\section{Appendix H \\ Originally Proposed Analyses: Research Questions 1 and 2}

\section{Research Question 1}

Do adolescents' civic justifications vary for different types of civic activity? Do civic justifications vary by age?

Hypothesis 1. Compared to fairness-oriented moral and structural justifications, adolescents will justify volunteering to feed the homeless using more welfare-oriented moral justifications.

To assess the relative use of welfare, fairness, and structural justifications for the volunteering category, a repeated measures ANOVA was performed with proportion scores reflecting the proportionate use of welfare, fairness, and structural justifications identified as the within-subjects factor. The results indicated that adolescents' use of welfare, fairness, and structural justifications for volunteering significantly differ, $F(2,477)=80.01, p<.001, \eta^{2}=.25$. Specifically, pairwise comparisons using Bonferonni corrections show that, when reasoning about volunteering, adolescents used proportionally more welfare-oriented moral justifications compared to fairness-oriented moral justifications $(\mathrm{p}<.001)$ and structural justifications $(\mathrm{p}<$ $.001)$.

Hypothesis 2. When justifying why people should take part in political protest or rally, adolescents will use more structural and fairness-oriented moral reasoning compared to welfareoriented moral reasoning.

The proposed hypothesis could not be examined as adolescents did not use welfare or fairness justifications when reasoning about social movement involvement. Instead, an alternative hypothesis was tested: adolescents will give structural justifications more when 
reasoning about social movement involvement compared to community service and standard political involvement. First, proportion scores were created that reflect adolescents' relative use of structural justifications across three civic behavior categories. A repeated measures ANOVA was performed with structural justification proportion scores identified as the within-subject factor. The results indicated that model was not statistically significant, $F(2,268)=.73, p=.48$. Next, dummy coded variables representing the presence vs. absence of a structural justification for each civic behavior category were used. A repeated measures ANOVA was performed with dummy coded structural justifications identified as the within-subject factor. Results showed that adolescents' use of structural justification significantly varied by civic behavior category, $F(2$, 719) $=3.93, p<.05, \eta^{2}=.01$. Pairwise comparisons using Bonferonni corrections indicated that structural justifications were used significantly more for protest $(M=.18)$ than standard political activity $(M=.14), p<.05$. Adolescents' use of structural justifications for protest did not significantly differ from their use of structural justifications for volunteering.

Hypothesis 3. Early adolescents will be more likely to use welfare-oriented moral justifications whereas late adolescents will be more likely to use structural and fairness-oriented moral justifications.

Given that welfare and fairness justifications were only present for responses to the volunteering question, proportion scores reflecting the relative use of welfare, fairness, and structural justifications for volunteering were analyzed. Separate 2 (early vs. late adolescence) X 3 (welfare, fairness, structural) ANOVAs were conducted on the proportion scores for each justification category. Results indicated that early and late adolescents did not significantly differ in their relative use of welfare-oriented moral justifications $[\mathrm{F}(1,477)=.99, \mathrm{p}=.319]$, fairness- 
oriented moral justifications $[\mathrm{F}(1,477)=1.67, \mathrm{p}=.197]$, or structural justifications $[\mathrm{F}(1,477)=.04$, $\mathrm{p}=.842]$ when reasoning about volunteering to feed the homeless.

\section{Research Question 2}

How are adolescents' civic justifications for all forms of civic engagement associated with their civic judgments?

A structural equation model was performed with civic justifications predicting civic prioritization judgments. Only hypothesized pathways were estimated (see Figure 5). Results were interpreted upon achieving adequate model fit, which were assessed with commonly used fit indices cut-offs: $\chi^{2} / d f<3.0$, CFI $>.95$ and RMSEA $<.05$.

Hypotheses 4-5. Moral justifications pertaining to welfare across all forms of civic activity will be positively associated with judgments about community service (i.e., viewing community service as more important, obligatory, and worthy of respect). Structural justifications and moral justifications pertaining to fairness across all forms of civic activity will be positively associated with judgments about social movement.

Welfare, fairness, and structural justifications for volunteering as well as structural justifications for each civic behavior were specified as exogenous variables predicting first-order latent variables representing adolescent civic judgments. Welfare-oriented moral justifications were associated positively with community service judgments $(\beta=.19, p<.001)$. Fairnessoriented moral justifications did not significantly predict social movement judgments. Structural justifications for protest, but not structural justifications for volunteering or voting, were associated positively with adolescent social movement judgments $(\beta=.08, p=.01)$. 


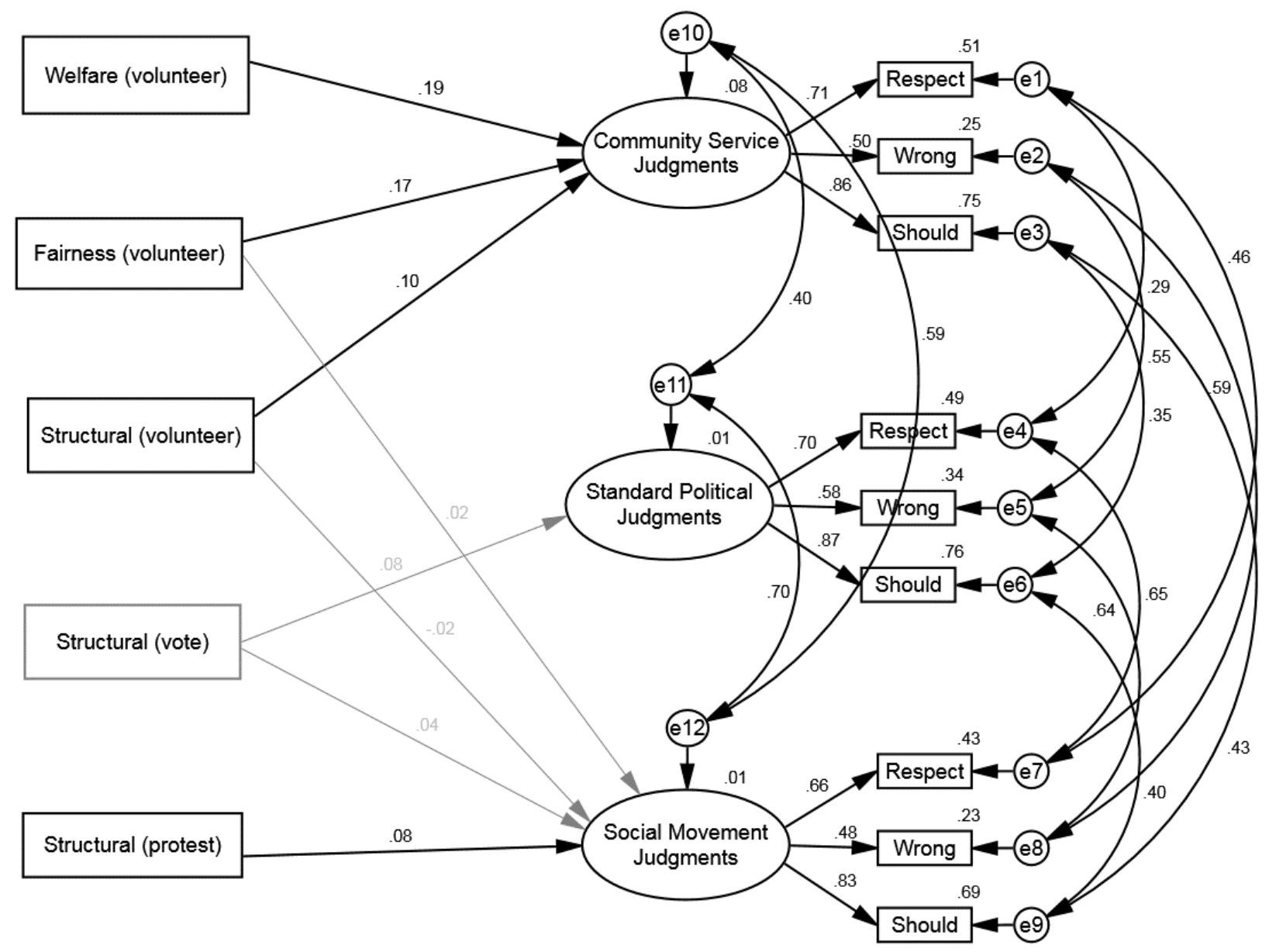

Figure 5. Welfare, fairness, and structural justifications across all forms of civic involvement predicting civic judgments. All estimates are standardized.

Note. Gray parameters were nonsignificant. All other parameters were significant at the $\mathrm{p}<.001$ level. 


\title{
Appendix I \\ Originally Proposed Content Codes for Civic Justifications
}

\author{
Content Codes: "Why should people volunteer to help feed the homeless?" \\ Welfare-oriented Moral Statements in which the welfare of others is taken into \\ consideration. Describes the recognition that others have needs and \\ that people have an obligation to fulfill the needs of others. Express \\ sympathy toward or concern for homeless individuals.

\section{EXAMPLE:} \\ "so they don't die and to take care of them; These are human \\ beings that deserve help"
}

\section{Justice-oriented Justifications for Volunteering}

Fairness: Perceived Reciprocity

Fairness: Inequity Obligation
Describes that helping the homeless will ensure the volunteer is helped if ever in the same circumstances. Describes the "golden rule" or recognition of the social contract

EXAMPLE:

"I am also a firm believer in the golden rule, and if you would want someone to feed you if you were homeless, you should help feed the homeless too"

Describes an obligation to help based on unequal distribution of resources/goods/abilities. Statements describe how one party has more and another party has less and due to this inequality, the party that has more has an obligation to help contribute to those with less.

\section{EXAMPLES:}

"They should because those people have literally nothing, and I think people who have the income to should definitely help" "The homeless, if they're lucky, have very little money to care for themselves with. Whereas, the middle class at least has a roof over their head and food. The homeless don't have that privilege. They struggle to make it by with what they have on their own. So those who have some food to spare or have excess food even, should donate that food to a drive, or give it to any homeless you see." 
Structural: Causes

Expressing reasons why individuals are homeless based on societal inequalities or situations beyond the individual's control. Reasons not pertaining to individual dispositions.

\section{EXAMPLES:}

"...because the economy is so bad"

"It is not always their faults that are in the situation that they for example the elderly who run out of money paying for a Medication and can no longer pay rent."

"The economy is so high today that many people have a hard time getting a job or affording a place to stay"

Structural: Community Describes how helping the homeless betters one's community. Betterment These statements describe more global or community-focused changes rather than one's obligation to help protect an individual's welfare. NOT limited to just community, but can include changes to societal institutions.

\section{EXAMPLES:}

"Because it would help our community and...benefit our economy" "People should take part in...community activities because it can make their community much stronger by uniting the people in it...community will grow to be at its best for the people that live in it."

\section{Personal Justifications for Volunteering}

Personal Benefit

Statements about the volunteer gaining something from helping feed the homeless. Any form of personal benefit.

\section{EXAMPLE:}

“...it might make you feel good inside, like you accomplished something. Also you could get volunteer hours, or community service hours."

Personal Prerogative Describes individuals' ambivalence toward volunteering. Individuals have a choice in whether or not they partake.

EXAMPLE:

"I think that this is completely up to the person" 


\section{Content Codes: "Why should people take part in political protest or rally?"}

\section{Justice-oriented Justification for Protest}

Structural: Fix

problems/Influence

government
Describes a recognition of problems within the current political system OR the acknowledgment of the ability to change the political system. NOT limited to just changes to government, recognizes changes to community as well.

\section{EXAMPLES:}

"They should because...you could change something or a law that should've been changed already."

"to help change or solve a problem with laws that may be considered unconstitutional"

"...because the protests may change something in the community for the better"

"March/preach what you want to be changed or over-ruled."

\section{Personal Justifications for Protest}

Personal Conviction

Personal Prerogative
Describes a justification based on an individual's personal beliefs. Describes a responsibility to act on one's beliefs.

\section{EXAMPLE:}

"People should take place in a political protest or rally so they can stand up for what they believe in."

Describes individuals' ambivalence toward protesting - they can if they want too, but they don't necessarily have too. Individuals have a choice in whether or not they partake. Expressing the idea that protesting is up to the individual.

EXAMPLE:

"I think that this is completely up to the person" 


\section{Content Codes: "Why should people vote in political elections?"}

\section{Justice-oriented Justification for Voting}

Structural: Fix

Problems/Influence

Government
Describes how voting can influence future events in citizens' lives. Focus on change/impact on a broad level, including policy modifications. Describes influencing the direction that government takes. Impacting or changing the country.

\section{EXAMPLE:}

"if you don't vote you are not helping your country improve"

\section{Personal Codes for Voting}

Personal Prerogative

Describes individuals' ambivalence toward voting - they can if they want too, but they don't necessarily have too. Individuals have a choice in whether or not they partake. Expressing the idea that protesting is up to the individual.

EXAMPLES:

"I think that this is completely up to the person"

"I don't think that anyone should be forced to vote" 


\section{References}

Flanagan, C. (2004). Volunteerism, leadership, political socialization, and civic engagement. In R. M. Lerner \& L. Steinberg (Eds.), Handbook of Adolescent Psychology (2nd ed., pp. 721-745).

Flanagan, C., \& Faison, N. (2002). Youth civic development: Implications of research for social policy and programs. Social Policy Report, 15, 1-16.

Flanagan, C., Kim, T., Pykett, A., Finlay, A., Gallay, E., \& Pancer, M. (2014). Adolescents' theories about economic inequality: Why are some people poor while others are rich? Developmental Psychology, 50(11), 2512-2525.

Galston, W. A. (2007). Civic knowledge, civic education, and civic engagement: A summary of recent research. International Journal of Public Administration, 30(6-7), 623-642. doi:10.1080/01900690701215888

Gilligan, C. (1982). In a different voice. Harvard University Press. Cambridge, Massachusetts. doi:10.2307/2067520

Halik, M., \& Webley, P. (2011). Adolescents' understanding of poverty and the poor in rural Malaysia. Journal of Economic Psychology, 32, 231-239. doi:10.1016/j.joep.2009.02.006

Harrah, J., \& Friedman, M. (1991). Economic socialization in children in a midwestern American community. Journal of Economic Psychology, 11, 495-513.

Helwig, C. (1995). Adolescents' and young adults' conceptions of civil liberties: Freedom of speech and religion. Child Development, 66(1), 152-166. 
Helwig, C. (1998). Children's conceptions of fair government and freedom of speech. Child Development, 69(2), 518-531.

Helwig, C., Arnold, M. L., Tan, D., \& Boyd, D. (2003). Chinese adolescents' reasoning about democratic and authority-based decision making in peer, family, and school contexts. Child Development, 74(3), 783-800.

Hyman, J. (2002). Exploring social capital and civic engagement to create a framework of community building. Applied Developmental Science, 6, 196- 202.

Jost, J. T., Federico, C. M., \& Napier, J. L. (2009). Political ideology: Its structure, functions, and elective affinities. Annual review of psychology, 60, 307-337.

Kahne, J., \& Westheimer, J. (1996). In the service of what? Phi Delta Kappan, 77, 592-599.

Killen, M. (2007). Children's social and moral reasoning about exclusion. Current Directions in Psychological Science, 16(1), 32-36.

Killen, M., \& Malti, T. (2015). Moral judgments and emotions in contexts of peer exclusion and victimization. In Advances in child development and behavior (1st ed., Vol. 48, pp. 249276). Elsevier Inc. doi:10.1016/bs.acdb.2014.11.007

McIntosh, H., \& Youniss, J. (2010). Toward a political theory of political socialization of youth. In L. R. Sherrod, J. Torney-Purta, \& C. A. Flanagan (Eds.), Handbook of research on civic engagement in youth (pp. 23-41). Hoboken, NJ: John Wiley \& Sons Inc. doi:10.1002/9780470767603.ch1

Metzger, A. (2007). Domain-specific judgments of civic and political engagement in late adolescence: Associations with adolescent activity involvement (Doctoral dissertation, University of Rochester). 
Metzger, A., \& Ferris, K. (2013). Adolescents' domain-specific judgments about different forms of civic involvement: Variations by age and gender. Journal of Adolescence, 36(3), 529538. doi:10.1016/j.adolescence.2013.03.003

Metzger, A., Oosterhoff, B., Palmer, C., \& Ferris, K. (2014). Dimensions of citizenship: Associations among adolescents' sociopolitical values and civic judgments. Political Science \& Politics, 47(2), 443-448.

Metzger, A., \& Smetana, J. G. (2009). Adolescent civic and political engagement: Associations between domain-specific judgments and behavior. Child Development, 80(2), 433-41. doi:10.1111/j.1467-8624.2009.01270.x

Metzger, A., \& Smetana, J. G. (2010). Social cognitive development and adolescent civic engagement. In L. R. Sherrod, J. Torney-Purta, \& C. A. Flanagan (Eds.), Handbook of Research on Civic Engagement in Youth (pp. 221-248). Hoboken, NJ: John Wiley \& Sons.

Nucci, L. P. (2001). Education in the moral domain. Cambridge, UK: Cambridge University Press.

Nucci, L. P., \& Gingo, M. (2010). The development of moral reasoning. The Wiley-Blackwell handbook of childhood cognitive development, 22, (pp. 420-445). Malden, MA: WileyBlackwell.

Roberts, F. \& Robinson, J.D. (2004). Interobserver agreement on first-stage conversation analytic transcription. Human Communication Research, 30(3), 376-410.

Sherrod, L. R., \& Lauckhardt, J. (2009). The development of citizenship. In R. M. Lerner \& L. Steinberg (Eds.), Handbook of adolescent psychology (3rd ed., Vol. 2, pp. 372-407). New York: Wiley \& Sons. 
Sherrod, L., Torney-Purta, J., \& Flanagan, C. (Eds.). (2010). Handbook of research on civic engagement in youth. Hoboken, N.J.: John Wiley \& Sons.

Smetana, J. G. (1985). Preschool children's conceptions of transgressions: Effects of varying moral and conventional domain-related attributes. Developmental Psychology, 21(1), 18.

Smetana, J. G. (2006). Social-cognitive domain theory: Consistencies and variations in children's moral and social judgments. In M. Killen \& J. G. Smetana (Eds.), Handbook of Moral Development (pp. 119-153). Mahwah, NJ: Erlbaum.

Smetana, J. G., \& Braeges, J. L. (1990). The development of toddlers' moral and conventional judgments. Merrill-Palmer Quarterly, 36(3), 329-346.

Smetana, J. G., Schlagman, N., \& Adams, P. W. (1993). Preschool children's judgments about hypothetical and actual transgressions. Child Development, 64(1), 202-214.

Smetana, J. G., \& Turiel, E. (2008). Moral development during adolescence. Blackwell handbook of adolescence, 8, 247.

Smetana, J. G., \& Villalobos, M. (2009). Social cognitive development in adolescence. In R. M. Lerner, \& L. Steinberg (Eds.), Handbook of adolescent psychology: Individual bases of adolescent development (3rd ed.) (pp. 187-228). Hoboken, NJ, US: Wiley \& Sons Inc.

Snell, P. (2010). Emerging adult civic and political disengagement: A longitudinal analysis of lack of involvement with politics. Journal of Adolescent Research, 25(2), 258-287.

Syvertsen, A. K., Wray-Lake, L., Flanagan, C. A., Osgood, D. W., \& Briddell, L. (2011). Thirty year trends in U.S. adolescents' civic engagement: A story of changing participation and educational differences. Journal of Research on Adolescence, 21(3), 586-594. doi:10.1111/j.1532-7795.2010.00706.x 
Tocqueville, A. (1848/1966). Democracy in America. NY: Harper \& Row.

Torney-Purta, J., Lehmann, R., Oswald, H., \& Schulz, W. (2001). Citizenship and education in twenty-eight countries: Civic knowledge and engagement at age fourteen. Amsterdam: International Association for the Evaluation of Educational Achievement.

Turiel, E. (2002). The culture of morality: Social development, context, and conflict. New York, NY, US: Cambridge University Press.

Turiel, E. (2008). Thought about actions in social domains: Morality, social conventions, and social interactions. Cognitive Development, 23(1), 136-154. doi:10.1016/j.cogdev.2007.04.001

Wainryb, C. (1991). Understanding differences in moral judgments: The role of informational assumptions. Child Development, 62(4), 840-851.

Walker, T. (2000). The service/politics split: Rethinking service to teach political engagement. Political Science \& Politics, 33(3), 646-649.

Walker, Tobi. (2002). Service as a pathway to political participation: What research tells us. Applied Developmental Science, 6(4), 183-188.

Watts, R. J., Diemer, M. A., \& Voight, A. M. (2011). Critical consciousness: Current status and future directions. In C. A. Flanagan \& B. D. Christens (Eds.), New Directions for Child and Adolescent Development (pp. 43-57). doi:10.1002/cd

Watts, R. J., \& Flanagan, C. (2007). Pushing the envelope on youth civic engagement: A developmental and liberation psychology perspective. Journal of Community Psychology, 35(6), 779-792. doi:10.1002/jcop.20178 
Westheimer, J., \& Kahne, J. (2004). Educating the "good" citizen: Political choices and pedagogical goals. Political Science \& Politics, 37(02), 241-247.

Westheimer, J., \& Kahne, J. (2004). What kind of citizen? The politics of educating for democracy. American Educational Research Journal, 41(2), 237-269. doi:10.3102/00028312041002237

Wray-Lake, L., \& Syvertsen, A. K. (2011). The developmental roots of social responsibility in childhood and adolescence. In C. A. Flanagan \& B. D. Christens (Eds.), Youth civic development: Work at the cutting edge. New Directions for Child and Adolescent Development, 134, 11-25.

Yates, M., \& Youniss, J. (1996a). A developmental perspective on community service in adolescence. Social Development, 5(1), 85-111.

Yates, M., \& Youniss, J. (1996b). Community service and political-moral identity in adolescents. Journal of Research on Adolescence, 6(3), 271-284.

Youniss, J., McLellan, J. A., \& Yates, M. (1997). What we know about engendering civic identity. The American Behavioral Scientist, 40(5), 620-631.

doi: $10.1177 / 0002764297040005008$ 
